\title{
Inclusion of flood diversion canal operation in the H08 hydrological model with a case study from the Chao Phraya River Basin - Part 1: Model development and validation
}

\author{
Saritha Padiyedath Gopalan ${ }^{1}$, Adisorn Champathong ${ }^{2}$, Thada Sukhapunnaphan ${ }^{2}$, Shinichiro Nakamura ${ }^{3}$,
} 5 Naota Hanasaki ${ }^{1}$

${ }^{1}$ Centre for Climate Change Adaptation, National Institute for Environmental Studies (NIES), 16-2 Onogawa, Tsukuba, Ibaraki 305-8506, Japan

${ }^{2}$ Royal Irrigation Department, 811 Samsen Road, Dusit, Bangkok, Thailand

${ }^{3}$ Royal Department of Civil Engineering, Graduate School of Engineering, Nagoya University, Building No. 9, Furo-cho,

10 Chikusa-ku, Nagoya 464-8603, Japan

Correspondence to: Saritha Padiyedath Gopalan (pgsaritha@nies.go.jp; charu666@gmail.com)

\begin{abstract}
Water diversion systems play crucial roles in assuaging flood risk by diverting and redistributing water within and among basins. For flood and drought assessments, including investigations of the effects of diversion systems on river discharge worldwide, the explicit inclusion of these systems into global hydrological models (GHMs) is essential. However, such representation remains in the pioneering stage because of complex canal operations and insufficient data. Therefore, we developed a regionalized canal operation scheme and implemented it in the H08 GHM for flood diversion in the Chao Phraya River Basin (CPRB), Thailand, which is a complex river network with several natural and man-made diversion canals and has been subject to severe flooding in the past, including recent years.
\end{abstract}

Region-specific validation results revealed that the enhanced H08 model with the regionalized diversion scheme could

20 effectively simulate the observed flood diversion pattern in the CPRB. Diverted water comprises approximately $49 \%$ of the annual average river discharge in the CPRB. The simulations further confirmed that the presented canal scheme had the potential to reduce flood risk in the basin by significantly reducing the number of flooding days. A generalized canal scheme with simple input data settings was also constructed for future global applications, providing insights into the maximum level of discharge reduction achievable with diversion of nearly $57 \%$ of the annual average river discharge of the CPRB. Overall,

25 the enhanced H08 model with canal schemes can be adapted and applied to different contexts and regions, accounting for the characteristics of each river network by maintaining the basic principles unaltered.

\section{Introduction}

Floods are among the most severe natural hazards, and flooding occurs naturally when river discharge exceeds the channel carrying capacity. Extreme flood events cause serious damage to human life, property, and agricultural systems with 30 disrupted economic activity (Padiyedath Gopalan et al., 2020; Yin et al., 2018). In past decades, annual losses caused by 
extreme flood events have been approximately tens of billions of US dollars; moreover, thousands of people have lost their lives in floods each year (Hirabayashi et al., 2013). Currently, almost 13\% of the global population (around one billion people) lives in floodplains (Di Baldassarre et al., 2013); this population are at risk of exposure to river flooding caused by extreme weather events (Alfieri et al., 2017). These flood issues have been addressed in many areas to a greater extent through the construction of 16.7 million reservoirs with a storage volume of nearly $8000 \mathrm{~km}^{3}$ (Lehner et al., 2011), along with other flood mitigation measures such as retention areas, afforestation, diversion dams, flood channels, etc.

Climate change may increase the intensity and frequency of extreme flood events and the global population exposed to flooding, thereby enhancing the magnitude of losses and fatalities caused by future floods (Dankers et al., 2014; Hirabayashi

40 et al., 2013; Hirabayashi et al., 2021; Jongman et al., 2015; Prein et al., 2017). This possibility has led to growing concern regarding the capacity of existing measures to manage future extreme flood events. Thus, impact studies of such extreme events are essential for developing suitable adaptation strategies towards a warming climate. For impact assessment of human interactions on flood discharge worldwide, the explicit inclusion of such interactions into global hydrological models (GHMs) is necessary (Bierkens, 2015; Boulange et al., 2021; Nazemi and Wheater, 2015a; 2015b). GHMs have been

45 progressively updated to include reservoir operations; water withdrawal and supply for irrigation, domestic, and industrial uses; groundwater dynamics; and seawater desalination (Burek et al., 2020; Ehsani et al., 2016; 2017; Hanasaki et al., 2018; Müller Schmied et al., 2021; Pokhrel et al., 2015; Sutanudjaja et al., 2018). However, the representation of water diversion systems remains in the pioneering stage because of complex dynamic canal operations and insufficient data.

50 Water diversion schemes account for about 14\% of total global water withdrawal (540 $\mathrm{km}^{3}$ ) in 2005 (ICID, 2005 ). Recently, McDonald et al. (2014) reported that nearly $184 \mathrm{~km}^{3}$ of water is diverted and moved over a distance of approximately 27000 $\mathrm{km}$ annually to meet the water demand in large cities globally. Later, Shumilova et al. (2018) presented the first global inventory of 110 water transfer megaprojects (existing, planned, and proposed) that serve multiple purposes including flood control, irrigation supply, industrial and domestic water supply, hydropower generation, habitat restoration, and navigation.

55 They revealed that the total volume of water transferred by existing systems was nearly $204 \mathrm{~km}^{3} / \mathrm{year}$ and would increase to $1910 \mathrm{~km}^{3} /$ year after the completion of planned and proposed diversion systems. These findings emphasize the necessity of including water diversion schemes in GHMs, which may otherwise overestimate water stress and flood risk.

In recent years, several authors have noted the impacts of water diversion on the status of water quality and groundwater

60 levels in water supplying and receiving areas (Tang et al., 2014; Wang et al., 2019; Ye et al., 2014). Although water diversion also plays a vital role in controlling floods in the water supplying areas, few attempts have been made to assess the effects of diversion canals on flood risk reduction. For instance, the effectiveness of diversion canals in decreasing floodwater levels was evaluated using the HEC-RAS hydraulic model at Pancoran in the Ciliwung River (Indrawati et al., 2018) and Ciliwung-Cipinang River, Indonesia (Nugroho et al., 2018). In addition, Wang et al. (2019) examined the impacts 
65 of inter-basin water diversion on flood control and drainage processes in a water-receiving lake basin in China using the MIKE model. Subsequently, Mel et al. (2020a) identified the optimal floodgate operation rules for diverting floodwater in the Bacchiglione-Brenta River network in Italy using the 2DEF hydrodynamic model; they also evaluated the applicability of those rules (Mel et al., 2020b). The use of hydrodynamic models to simulate floodwater diversion has greatly clarified the effects of such operations on flood risk reduction. However, previous studies have mainly considered the relationships between regional flood characteristics and associated diversion canal operation schemes, which have limited applicability in other regions. Floodwater diversion schemes that can be integrated into GHMs are still lacking, and their impacts on global and regional flood control are relatively unexplored.

Although flood damage is expected to increase globally by the end of the $21^{\text {st }}$ century, countries in Southeast Asia will experience a particularly severe increase in flood risk (Winsemius et al., 2016). Thailand is the second-largest economy in Southeast Asia, and $58 \%$ of all disasters in that country have been generated by floods (JICA, 2015). Floods in Thailand have caused $27 \%$ of total disaster-related deaths; the greatest proportion can be attributed to the 2011 flood disaster in the Chao Phraya River basin (CPRB), the largest basin in Thailand. The estimated economic losses from the 2011 flood were approximately USD 46.5 billion (JICA, 2015; Komori et al., 2012; World Bank, 2012). The CPRB has been subject to

80 severe flooding in the past, including in recent years (Komori et al., 2012; Kotsuki et al., 2014; Kure and Tebakari, 2012; Watanabe et al., 2014). Recent studies have evaluated the applicabilities of various adaptation strategies, including afforestation (Takata and Hanasaki, 2020) and reservoir operation (Padiyedath Gopalan et al., 2021), for reducing flood risk in the CPRB; they concluded that further adaptation measures are needed to address future floods. Although the CPRB has several natural and man-made diversion canals, their adaptation potential remains largely unknown, because these diversion systems have not been integrated into hydrological models.

Therefore, the focus of this study was to develop a flood diversion canal operation scheme for the CPRB that was carefully designed to adapt for future global applications. The scheme developed here was implemented in the H08 GHM for future floodwater management in complex river networks worldwide. The H08 GHM is a pioneering model composed of six

90 modules that explicitly consider numerous human interactions with the hydrological cycle (Hanasaki et al., 2008a; 2008b; 2018). The H08 model has been successfully applied at global and regional scales (Hanasaki et al., 2008b; Masaki et al., 2017; Masood et al., 2015; Mateo et al., 2014). It has considered aqueduct water transfer to represent irrigation water supply (Hanasaki et al., 2018). However, floodwater diversion has not been implemented thus far because of the challenges involved in its implementation. Hence, in this study, flood control was considered as the primary feature of diversion canals 95 because of severe flooding issues in the CPRB, although water diversion systems could function as both floodways and irrigation channels. The diversion system could divert floodwater to a downstream section of the same river; to nearby tributaries within or outside the basin; and to retention areas for temporary storage. 
The aim and novelty of this study were the construction of a regional floodwater diversion scheme for the CPRB that is flexible and easily modifiable for future application in any region worldwide. Based on the aforementioned discussions, this study is composed of the following objectives:

(i) Develop a floodwater diversion scheme for the CPRB and enhance the H08 GHM by incorporating this scheme into the model. The water diversion scheme includes diversion canals and retention areas to divert and store water, respectively.

(ii) Validate the effectiveness of the enhanced H08 model for reproducing the water diversion process in the CPRB.

(iii) Analyze the impacts of diversion canals and retention areas on flood management in the CPRB.

\section{Materials and methods}

\subsection{H08 model}

H08 is an integrated global water resources model that consists of six modules: land surface hydrology, river routing, crop growth, reservoir operation, environmental water, and anthropogenic water withdrawal (Hanasaki et al., 2008a; 2008b) to quantify natural as well as anthropogenic water availability and use in the past, present, and future. Each of the modules can run separately with spatial and temporal resolutions of $0.5^{\circ} \times 0.5^{\circ}$ and 1 day, respectively. The land surface hydrology module is based on a bucket model (Manabe, 1969) that simulates the energy and water balances at the land surface from forcing data. Runoff, the major output from the land surface hydrology module, is then fed into the river routing module, which accumulates the runoff and outputs as streamflow along the river network from upstream to downstream. This module does not account for the effect of water infrastructures and thereby simulates the natural water cycle in cooperation with the

115 land surface hydrology module. Evapotranspiration, another major product of the land surface hydrology module, is used in the crop growth module to estimate global cropping calendars and crop yields. The reservoir operation module follows operating rules for individual reservoirs based on their primary purpose (i.e., irrigation or non-irrigation water supply). The environmental water module receives streamflow estimates from the river routing module and calculates the river flow that should be maintained in the river channel to support the aquatic ecosystem. Finally, the six modules are coupled to run all processes (including anthropogenic water withdrawal) in an integrated manner. In the coupled model, irrigation water demand (simulated by the crop growth module) and streamflow (estimated by the river routing and reservoir operation modules) are utilized to estimate anthropogenic water withdrawal. For a detailed description of the H08 hydrological model, please see https://h08.nies.go.jp/h08/index.html.

\subsection{H08 model enhancement for flood diversion canals}

125 The latest version of the H08 model enables water abstraction from various water sources (e.g., surface water and groundwater); it explicitly includes groundwater recharge, groundwater abstraction, aqueduct water transfer, local reservoirs, irrigation return flow and delivery loss, and seawater desalination schemes (Hanasaki et al., 2018). These changes transform H08 into one of the most detailed GHMs for attributing different water sources available to human society. However, the 
model still lacks representation of floodwater diversion systems; the implementation of this representation will provide viable adaptation scenarios towards a warming climate.

To overcome this limitation, we enhanced the H08 model by implementing diversion canal schemes. Although the primary objective of diversion canals assessed in this study is flood control, the implemented canal schemes could function as both floodways (offering different routes for excess water flow) and water supply canals (redistributing water from one region to another region that is experiencing water shortage) in future global applications. If flood control is the primary purpose of a canal, the river flow is diverted to the floodway (flood diversion canals) only during the wet season. In contrast, river flow is diverted to water supply canals during the dry season to supply water for various purposes, including irrigation. The schematic diagram of canal operation for the wet and dry seasons are shown in Fig. 1. For multi-purpose canals, river flow is diverted throughout the year to provide water supply during the dry season and flood control during the wet season. Because this study included flood diversion, water supply, and multi-purpose canals in the implemented diversion scheme, this scheme can be applied to any region based on the prevalence of each canal type and the context in which canal operations are needed.

During the dry season, the diversion system operates in a manner such that, if river discharge is greater than the environmental flow requirement $\left(Q>Q_{e n v}\right)$ at the origin, a minimum amount of flow $\left(Q_{\text {min }}\right)$ is diverted from the river channel to the canal system. This operation leads to the emergence of two cases concerning river discharge after diversion $\left(Q-Q_{\min }\right)$, which are expressed as follows:

$$
D_{d r y}=\left\{\begin{array}{ll}
Q_{\min } & ; \text { if }\left(Q-Q_{\text {min }}\right)>Q_{\text {env }} \\
Q-Q_{e n v} & ; \text { if }\left(Q-Q_{\text {min }}\right)<Q_{e n v}
\end{array}\right\}
$$

where $D_{d r y}$ is water diversion during the dry season; $Q_{\min }$ is minimum flow diversion; $Q_{\text {env }}$ is the environmental flow requirement; and $Q$ is the river discharge at the origin of diversion. These two cases represent low flow scenarios (Supplementary Fig. S1a and b) and can be explained as follows: (i) if the river discharge after diversion $Q-Q_{m i n}>Q_{e n v}$, then $Q_{\min }$ is diverted, and (ii) if the river discharge after diversion $Q-Q_{\min }<Q_{\text {env }}$; under such circumstances, the remaining river discharge after meeting the environmental flow requirement $\left(Q-Q_{\text {env }}\right)$ is diverted into the canal. Using these criteria, environmental flow is maintained in both cases. No flow is diverted to the canal if river discharge is lower than environmental flow. After the diversion into canals, a portion of the diverted water (either a fixed percentage or based on the water supply needs including irrigation) is supplied to nearby areas $\left(Q_{\text {sup }}\right)$ along its flow route until flow either diminishes to zero or reaches its destination. The surplus water supply that was not completely utilized for irrigation $\left(Q_{\text {sup }}-Q_{\text {irr }}\right)$ is returned to the main channel. The remaining canal flow, if any, is returned to the canal's destination, as shown in Supplementary Fig. S1a and b. 
During the wet season, diversion canals are designed to divert the floodwater from the main channel. Typically, a flood occurs when river discharge exceeds the river channel carrying capacity. From this perspective, two relevant cases can be identified based on whether river discharge $(Q)$ is greater or smaller than the river channel carrying capacity $\left(Q_{\text {rivcap }}\right)$. Each of these cases includes two sub-cases, leading to the following four cases:

$$
D_{\text {wet }}=\left\{\begin{array}{ll}
Q_{\text {cancap }} & \text {; if } Q>Q_{\text {rivcap }} \text { and }\left(Q-Q_{\text {cancap }}\right)>Q_{\text {env }} \\
Q-Q_{\text {env }} & \text {; if } Q>Q_{\text {rivcap }} \text { and }\left(Q-Q_{\text {cancap }}\right)<Q_{e n v} \\
Q_{\text {min }} & \text {; if } Q<Q_{\text {rivcap }} \text { and }\left(Q-Q_{\text {min }}\right)>Q_{\text {env }} \\
Q-Q_{\text {env }} & \text {; if } Q<Q_{\text {rivcap }} \text { and }\left(Q-Q_{\text {min }}\right)<Q_{\text {env }}
\end{array}\right\}
$$

where $D_{\text {wet }}$ is water diversion during the wet season and $Q_{\text {cancap }}$ is the maximum canal carrying capacity. The first case corresponds to the flood flow scenario, where $Q>Q_{\text {rivcap }}$ (Supplementary Fig. S1c and d). The two sub-cases of case 1 can be described as follows: (i) if the river discharge after diversion $Q-Q_{\text {cancap }}>Q_{e n v}$, then $Q_{\text {cancap }}$ is diverted, and (ii) if the river discharge after diversion $Q-Q_{\text {cancap }}<Q_{\text {env }}$, then the remaining river discharge after meeting the environmental flow requirement $\left(Q-Q_{e n v}\right)$ is diverted into the canal. The second case $\left(Q<Q_{\text {rivcap }}\right)$ represents non-flood flow scenarios (Supplementary Fig. S1e and f); however, a minimum flow is diverted from the main channel to reduce flooding at downstream locations. The two sub-cases of case 2 can be explained as follows: (i) if the river discharge after diversion $Q-$ $Q_{\text {min }}>Q_{e n v}$, then $Q_{\text {min }}$ is diverted, and (ii) if the river discharge after diversion $Q-Q_{\text {min }}<Q_{e n v}$, then $Q-Q_{e n v}$ is diverted into the canal, as in the dry season. Canal diversion remains zero during periods of environmental flow. The diverted canal water will drain into retention areas $\left(Q_{\text {ret }}\right)$, if present (Supplementary Fig. S1c-f). Excess water from retention areas will move toward the destination when the storage capacity of the retention areas becomes full. These retention areas or ponds store water temporarily to reduce the flood peak; thus, they extend flow duration (Tourment et al., 2016). At the end of each year, retention storage is assumed to evaporate $(E)$ fully and retention storage at the beginning of the following year is assumed to be zero.

Flow that is diverted from the main channel into canals eventually splits into four major components, as shown in Fig. 2. The first component is "returned discharge" (A), which is the canal flow returning to destinations such as the downstream section of the same river or nearby rivers or tributaries within the basin. This returned discharge increases flow at the destination and reduces flow at the origin. The second component is "supply to near grids" (B), which is the portion of the diverted water supplied to each grid cell along its flow route. This component is enabled only during the dry season to augment water supply needs. At some point, the diverted water flows to nearby river basins or drains into the sea. This component is designated as "flow out of the basin" (C); it alters the water balance of the river system in question and should be included in water budget analysis to avoid unexplained water imbalance. A portion of the diverted canal flow drains into the retention areas, and the floodwater stored in these areas are called the "retention storage" (D). The storage of floodwater in retention areas is allowed only during the wet season to supplement flood control capacity alongside diversion systems. All of these components can be customized (enabled/disabled) for each basin under consideration. 


\subsection{Input data for canal operations}

To conduct canal operations, the following data are needed:

(i) Geographic location of the canal: The geographic locations of the canal's origin and destination are needed to identify the donor and recipient systems; this is the minimum information required to proceed further. In addition, the location of the entire canal route enables the identification of areas receiving water from the canal system.

(ii) Location and areal extent of retention areas: The geographic locations of possible retention areas (e.g., ponds, wetlands, and low-lying areas) and their areal extents available for storage of floodwater.

(iii) River channel carrying capacity: The carrying capacity of the river channel at the origin of the canal diversion should be obtained. When river discharge at the diversion point is greater than the carrying capacity, water is diverted into the canal.

(iv) Canal carrying capacity: The carrying capacity of the canal should be noted; this represents the maximum flow that can be diverted under flood conditions.

(v) Minimum flow diversion: A minimal amount of flow is diverted from the river channel to reduce downstream flooding under non-flood conditions in the wet season and supply water during the low flow conditions in the dry season.

(vi) Days of diversion per year: Regional wet and dry seasons must be identified to enable the diversion of water under flood, non-flood, and low flow conditions.

\subsection{Canal operation schemes}

A canal diversion scheme that utilizes the observed values of all input data (described in section 2.3) specific to a particular

region is described hereafter as the regionalized canal scheme. However, when the model is applied to data-scarce regions and periods, implementation of the diversion system using the input data described in section 2.3 becomes strenuous. In addition, when this diversion scheme is implemented in GHMs for global analysis, extensive data are needed for each river basin, further hampering the application of GHMs. To overcome these difficulties and support the future global application of the canal diversion scheme, we tested the H08 model with simple input data settings that can be derived from river discharge alone (hereafter designated as the generalized canal scheme).

The generalized canal scheme is regarded as the preliminary survey for future global applications. In the generalized scheme, the geographic location of the canal, as well as the locations and areal extents of retention areas, should be estimated for the study region in a manner similar to the regionalized scheme. Information regarding canal systems can be collected from peer-reviewed articles, official websites, reports from governmental and non-governmental organizations, and newspapers (Shumilova et al., 2018). Based on this information, the geographic locations of the canal origin, flow path, and destination can be extracted using the Google Earth application. Similarly, low-lying areas, ponds, and lakes can be recognized as retention areas, if present. 
The input data for river carrying capacity, canal carrying capacity, and minimum flow of diversion is difficult to collect for all canal systems to support the global application of the model. The river channel carrying capacity $\left(Q_{\text {rivcap }}\right)$ is the maximum flow that a channel cross-section can accommodate. When river discharge exceeds $Q_{\text {rivcap }}$, flooding occurs. This relationship indicates that the $Q_{\text {rivcap }}$ at any station is closely associated with the high flow of that cross-section. Therefore, the $\mathrm{Q}_{5}$ value (high flow) derived from pristine flow was used in the generalized scheme to represent $Q_{\text {rivcap }}$. Flow values above $Q_{5}$ will create flood flow conditions at specified locations, thus requiring the diversion of water from the main channel to reduce flood risk. Additionally, the $\mathrm{Q}_{50}$ value (median flow) is used to illustrate the canal carrying capacity that supports the diversion of the approximate long-term mean daily flow in the generalized scheme. This flow level ensures that a substantial amount of water is diverted to the canal system during floods. Lastly, the minimum flow diversion is represented by the $\mathrm{Q}_{90}$ value, which is a direct indication of low flow. The number of days of diversion is based on the lengths of the wet and dry seasons; therefore, region-specific data are needed under both diversion schemes.

\section{Study area and model simulations}

\subsection{Study area}

The diversion canal system was developed for the CPRB, which is the largest river basin in Thailand, with an area of approximately $158,000 \mathrm{~km}^{2}$ that covers more than one-third of the total area of Thailand (Fig. 3). The CPRB is home to about 30 million people (40\% of the country's population) and includes the capital city, Bangkok, which is located at the Chao Phraya River delta. Bangkok contains 50\% of the basin's population; generates almost $80 \%$ of the basin's gross domestic product; and is the political, commercial, industrial, and cultural hub of Thailand (Bond et al., 2018).

The CPRB is divided into an upper and a lower basin at Nakhon Sawan, (C.2 station) as shown in Fig. 3 (Komori et al., 2012). The upper basin includes four major tributaries (i.e., Ping, Wang, Yom, and Nan) that have headwaters originating from the northern part of the country. The Wang joins with the Ping River and the Yom joins with the Nan River; the subsequent confluence of the Ping and Nan Rivers at Nakhon Sawan is the beginning of the Chao Phraya River. From Nakhon Sawan, the river flows to the lower basin through Bangkok and finally drains into the Gulf of Thailand (Tebakari et al., 2012). Other tributaries (i.e., Pasak and Sakae Krang Rivers) join the Chao Phraya River in the lower basin.

250 Thailand experiences two seasons: a wet season (May-October) and a dry season (November-April). The rainfall distribution over the basin significantly varies, ranging from 1,000 to $2,000 \mathrm{~mm}$. Nearly $90 \%$ of total annual rainfall is received during the wet season, leading to increased flood risk (Bond et al., 2018). The lower basin and downstream parts of the Yom basin have gentle slopes (Fig. 3) and reduced channel carrying capacity; this makes the region highly prone to flooding (Komori et al., 2012). The severe flooding that occurred during the 2011 monsoon season inundated the lower basin 
and downstream parts of the Yom and Nan Rivers (Mateo et al., 2014), causing over 800 deaths and substantial economic losses of USD 46.5 billion (World Bank, 2012). To minimize flooding caused by reduced channel carrying capacity and gentle slopes at various locations, the Thai government has implemented measures to protect the CPRB by constructing dams and numerous diversion canals (both natural and man-made).

\subsection{Water infrastructures in the CPRB}

\subsubsection{Canal system}

The CPRB is a complex river network with several natural and man-made diversion canals, as shown in Fig. 4. These canals are either for flood diversion or multi-purpose; they were implemented to mitigate extreme flood events, protect high-density business and residential areas, and provide irrigation water supply. Water diversion into these canal systems is controlled by barrages installed on the Chao Phraya River. Based on the literature review (JICA, 2013; Tamada et al., 2013) and maps collected from the Royal Irrigation Department (RID) of Thailand, 11 canal systems were identified in the CPRB with direct intakes from the main river channel (Fig. 4). Details of these canal systems are provided in Table 1. Of these 11 canal systems, two are in the Yom basin; flooding is common in that basin because (i) large-scale flow regulating structures are absent, (ii) the downstream area exhibits a gentle slope, and (iii) various locations have low channel carrying capacities. To alleviate these issues, two diversion canals have been implemented to divert water from the Yom River to the Nan River, downstream reaches of the Yom River, and nearby low-lying paddy fields during floods (Fig. 4a).

The remaining nine canal systems are in the lower CPRB, where flood hazards are frequent because the channel's carrying capacity progressively decreases from Nakhon Sawan (C.2 station) to Ayutthaya (C.35 station) as shown in Fig. 4b. To reduce downstream flooding near Ayutthaya, the Chao Phraya diversion dam on the Chao Phraya River allocates water to multiple canals (i.e., Chainat-Pasak, Makham Thao-Uthong, Tha Chin, Noi, and Chainat-Ayutthaya), immediately upstream of the diversion dam (canals 3-7, respectively, in Fig. 4b). Among these five canals, the Tha Chin River is a major distributary of the Chao Phraya River that flows through Bangkok and drains into the Gulf of Thailand. This river is considered as a canal system because of its ability to carry floodwater away from the Chao Phraya River. Similarly, the Noi River, which diverts water from the main channel, is considered as a diversion canal. Together, these 5 canals limit flow to approximately $2840 \mathrm{~m}^{3} / \mathrm{s}$ at the Chao Phraya diversion dam (Fig. 4b). Downstream of the Chao Phraya Dam, the Lopburi River splits off from the Chao Phraya River after receiving surplus water; it then joins the Pasak River. The Lopburi River has one short tributary, the Bang Kaeo River, which originates from the Chao Phraya River. These two canal systems together control floods between Sing-Buri and Ang-Thong. Finally, the Phong Pheng and Bang Ban canals divert water from the main channel to reduce the flow at Ayutthaya; they then join the Noi River, which subsequently recombines with the 
Four canal systems in the basin are solely responsible for flood control: the Yom-Nan diversions in the upper CPRB and the Lopburi and Bang Kaeo canals in the lower CPRB. The remaining seven canals in the lower CPRB serve both flood control and irrigation water supply purposes. Among all canals in the basin, two remove water from the basin: the Makham ThaoUthong (providing irrigation water to areas that lie outside the basin) and Tha-Chin (emptying into the Gulf of Thailand, similar to the Chao Phraya River) canals. The diversion of river discharge from the main channel to canals is controlled by the operation of diversion dams and other water regulation structures (names of structures are provided in Table 1). However, the gravity transfer of water occurs at the origins of the Phong Pheng and Bang Ban canals.

Timely diversion of flood flows from the main channel is essential for controlling flooding downstream of the lower CPRB, which is a flood-prone area affected by strong tides. Therefore, two questions arise at the time of diversion: when to divert and how much water to divert. Whenever river discharge exceeds the channel carrying capacity at the origin of a diversion canal, an amount no greater than the canal carrying capacity should be diverted to control flooding. Furthermore, to en able irrigation water supply because canals in the CPRB are solely used to provide water for irrigation and not for other sectors, a minimum flow amount is diverted during the dry season. Table S1 shows the observed river channel carrying capacity, canal carrying capacity, and minimum flow of diversion at the origins of the 11 canal systems (Tamada et al., 2013).

\subsubsection{Reservoirs}

Several dams have been constructed in the CPRB since 1950 to store water from the wet to the dry season, providing flood control and water supply (Bond et al., 2018; Tebakari et al., 2012). Therefore, the Chao Phraya River is highly regulated by existing reservoirs. The GRanD global dam database (Lehner et al., 2011) lists 39 dams in Thailand, in which Bhumibol and

305 Sirikit are the two major reservoirs in the Chao Phraya River. Together, the Bhumibol and Sirikit control approximately $22 \%$ of runoff from the basin, with a combined storage capacity of 23 billion $\mathrm{m}^{3}$ (Bond et al., 2018; Komori et al., 2012). There

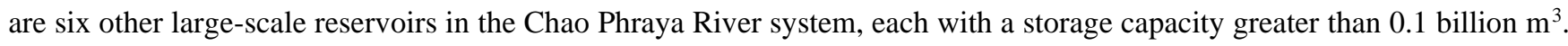
Detailed information regarding the reservoirs along the CPRB is provided in supplementary material S2.2; reservoir locations in the basin are shown in Figure 4.

\subsection{Input data sources and assumptions for canal operation in the CPRB}

Prior to beginning model setup and simulation, the input data required for simulations in the CPRB were finalized for both regionalized and generalized canal schemes, as follows:

(i) Geographic location of the canal: The origin, destination, and flow path of each canal system were identified using the Google Earth application and digitized into the H08 model. Both regionalized and generalized schemes employed the 315 same geographic location data for simulations.

(ii) Location and areal extent of retention areas: In the H08 model, land grid cells are divided into four sub-cell types: double-crop irrigated, single-crop irrigated, rainfed cropland, and non-cropland (Hanasaki et al., 2008a). Irrigation water 
is applied to the irrigation sub-cells to maintain appropriate soil moisture during the cropping period, while no irrigation is supplied to rainfed and non-cropland sub-cells (Hanasaki et al., 2018). In most Southeast Asian countries, rainfed cropland comprises low-lying paddy fields that are natural floodplains and cannot be cultivated during the rainy season because of flooding (Jamrussri et al., 2018). Thus, for the sake of brevity, the areal fraction of rainfed croplands (Siebert et al., 2010) presumedly located near the canal route was regarded as the areal fraction of retention areas for both canal schemes because our region of interest is in a Southeast Asian country. The retention areas modeled under the regionalized scheme were then refined by matching the areal extent of rainfed croplands near the canal networks with the data provided by the RID (geographic location and areal extent of several lowland areas, such as paddy fields, that are currently used as flood retention areas in the basin).

In both schemes, the area of retention ponds in each grid cell was obtained by multiplying the area of that grid cell with the areal fraction of rainfed cropland. Then, this area was multiplied with the depth of water storage (assumed to be $1 \mathrm{~m}$ in this study based on recommendations from the RID) to calculate the storage capacity of the retention ponds. The diverted canal flow was assumed to be temporarily stored in these rainfed croplands until their storage capacity was reached. Further details regarding the inclusion of canal systems and retention areas in the H08 model are provided in supplementary material S3.

(iii) River channel carrying capacity: A slightly adjusted version of the observed channel carrying capacity was used for the regionalized canal scheme. Because the simulated streamflow is slightly underestimated, the river carrying capacity was adjusted to avoid overestimation of canal effects. This adjustment was conducted by matching the simulated and observed fractions of river flow that are diverted into the canals during the wet and dry seasons. In contrast, $\mathrm{Q}_{5}$ values derived from natural flow levels at various stations were used for the channel carrying capacity in the generalized canal scheme. Further details are provided in supplementary material S3.

(iv) Canal carrying capacity: Similar to the river carrying capacity, a slightly adjusted version of the observed canal carrying capacity was used in the regionalized scheme, while $\mathrm{Q}_{50}$ values represented carrying capacity in the generalized scheme.

(v) Minimum flow diversion: For the regionalized scheme, the minimum flow to be diverted was obtained from historic canal operation data provided by the RID; these flow data were then adjusted. Under the generalized scheme, these data comprised $\mathrm{Q}_{90}$ values, as explained in section 2.4.

345 Canal water can be supplied to grid cells near the canal flow route based on the water requirement of each grid cell (i.e., supply to near grids). However, for simplicity, $10 \%$ of diverted water is supplied to each of the nearby grid cells in this modelling approach that was further utilized for irrigation. A detailed comparison of the two schemes in terms of input data is provided in Table 2 . 


\subsection{Model setup and simulations}

350 We previously adapted the $\mathrm{H} 08$ model to the calculation domain of $13-20^{\circ} \mathrm{N}$ and $97-102^{\circ} \mathrm{E}$ at a spatial resolution of 5 arcmins for application in the CPRB (Padiyedath Gopalan et al., 2021). In that model setup, only three modules (land surface hydrology, river routing, and reservoir operation) of the H08 model were enabled. Four key parameters of the land surface hydrology module were derived for the CPRB region by calibrating the model at Nakhon Sawan, while generic operation rules of reservoirs in the global setup were improved by including release rates for the wet and dry seasons, as well as an upper rule curve based on observed historical reservoir operations in the CPRB. The simulations were conducted using the IMPAC-T dataset (Kotsuki et al., 2014), which comprises seven meteorological variables including temperature, specific humidity, short-wave radiation, long-wave radiation, atmospheric pressure, wind speed, and precipitation from 1980-2004. In that study, we successfully validated river discharge and dam operation in the basin.

For simulations in the present study, we maintained the same model setup for the CPRB, except for model calibration. The H08 model was recalibrated for the CPRB because the present study uses an upgraded version of the H08 model that includes four additional parameters (a total of eight parameters) in the land surface hydrology module, representing groundwater recharge and abstraction (Hanasaki et al., 2018). The eight key parameters of the land surface hydrology module were derived through calibration of the model at Nakhon Sawan. The calibrated parameters and their values are shown in Table S4. Furthermore, five types of discharge simulation were conducted (Table 3) from 1980 to 2004 (total duration of 25 years as follows: (i) naturalized discharge, where all types of water infrastructure were disabled; (ii) regulated discharge, where the reservoir operation module was enabled; (iii) irrigated discharge, where both the reservoir operation module and irrigation water abstraction module were enabled; (iv) regionalized discharge, which is irrigated discharge with the regionalized canal scheme enabled; and (v) generalized discharge, which is irrigated discharge with the generalized canal scheme enabled. Equilibrium for all model state variables was achieved using spin-up calculations.

Initially, model calibration and validation were conducted using naturalized discharge, and the efficacy was evaluated based on Nash-Sutcliffe efficiency (NSE; Nash \& Sutcliffe, 1970). For model validation, daily river discharge data at various locations in the CPRB (green colour gauging stations in Fig. 4) were collected from the RID. In addition, the capability of the H08 model to reproduce regulated and irrigated discharges at Nakhon Sawan using the calibrated parameters was examined. Regionalized canal operations were calibrated for each diversion canal system to mimic the available observed data provided by the RID. Calibration was conducted by controlling the fraction of river flow to be diverted into the canals during the wet and dry seasons, with reference to the observed fraction of water diverted. Although the wet season ends in October (section 3.1), May-December was regarded as the wet season in this study based on observed reservoir release

380 (Padiyedath Gopalan et al., 2021) and canal diversion operations. Similarly, the dry season was redefined as January-April for simplicity of simulation. 


\section{Results}

The H08 model was calibrated and validated for naturalized, regulated, and irrigated discharges in the CPRB; the results are shown in supplementary material S4.

\subsection{Validation of seasonal water diversion}

The observed and simulated fractions of river flow diverted into the canals with respect to a reference gauging station are listed in Table 4 for the wet and dry seasons. For each canal system, the nearest upstream gauging station was used as the reference gauging station (Column 2 of Table 4; Fig. 4) to determine the fraction of water diverted. The regionalized simulation closely agreed with the observed diverted fraction for all canal systems considered during both dry and wet seasons. In the generalized simulation, the diverted fraction was reasonably reproduced at many stations; it substantially differed from the observations at some stations during both seasons. On average, the regionalized and generalized simulations diverted $8.78 \%$ and $22.55 \%$ of river discharge, respectively, compared with the observed dry-season discharge diversion of $9.25 \%$. The average values of observed, regionalized, and generalized diverted fractions during the wet season were $11.24 \%, 11.90 \%$, and $11.71 \%$, respectively.

Simulated monthly mean canal flows (generalized and regionalized) at 11 canal origins (Table 1) are shown in Fig. 5, along with observed diverted canal flow. Monthly mean values were used to validate canal operations because observed canal operation data are available for a different period from the simulation time frame (1980-2004). The regionalized canal flow showed good agreement with the observed flow at all stations except the Lopburi and Bang Kaeo canals. The observed data at these two stations included missing values, which reduced the predictive accuracy of flow diversion. From a seasonal perspective, the model exhibited good reproduction of canal flows during both dry and wet seasons. However, the generalized canal flow exhibited disparities compared with the observed flow at Makham Thao-Uthong, Tha Chin, ChainatAyutthaya, Lopburi, Bang Kaeo, and Phong Pheng stations. These disparities can be attributed to uncertainties in the $\mathrm{Q}_{5}$, $\mathrm{Q}_{50}$, and $\mathrm{Q}_{90}$ values assigned to the channel carrying capacity, canal carrying capacity, and minimum flow diversion, respectively; they can also be attributed to missing values at the Lopburi and Bang Kaeo stations.

The H08 model accurately reproduced canal operations in the CPRB under the regionalized canal scheme. Although the primary purpose of the implemented canal scheme was flood control during the wet season (May-December), the model was also able to replicate the diversion pattern during the dry season (January-April). This result reveals that the regionalized canal scheme can also be successfully used to provide water supply during the dry season in addition to the flood control during the wet season. 


\subsection{Breakdown of the diverted canal flow}

The four components of diverted canal flow are returned discharge, supply to near grids, flow out of the basin, and retention storage, as described in section 2.2. Fig. 6(a) and (c) show the amount of flow transferred from the canal systems to each of these components under the regionalized and generalized schemes, respectively, from 1980 to 2004 . The maximum and minimum values of diverted annual canal flow were approximately 22 and $7 \mathrm{~km}^{3}$ in the years 1980 and 1991 , respectively, under the regionalized scheme. These values were similar to the maximum and minimum values obtained from the generalized scheme $\left(21 \mathrm{~km}^{3}\right.$ in 1980 and $9 \mathrm{~km}^{3}$ in 1991). This consistency reveals that the generalized scheme could predict the annual flow diversion pattern in the basin. Fig. 6 shows that most diverted water is gradually returned to the destination points under both canal schemes. The supply to near grids and flow out of the basin were nearly equivalent in the regionalized scheme, whereas flow out of the basin was dominant in the generalized scheme. This dominance in the generalized scheme can be attributed to the high carrying capacity of canals that flow out of the basin. The last component, retention storage, was small and comparable under both schemes.

425 Although the total flow diverted to the canal systems was similar under both schemes, the percentage of canal flow transferred to each component differed, as shown in Fig. 6(b) and (d). The annual average flow diversion from the river channel to the canal system under the regionalized scheme was nearly $13 \mathrm{~km}^{3} / \mathrm{year}$, which constitutes nearly $49 \%$ of the annual average river discharge in the CPRB (26.6 km³/year). The annual average flow diversion under the generalized scheme was approximately $15 \mathrm{~km}^{3} /$ year (57\% of the annual average discharge in the CPRB). The share of canal flow attributed to each component was in the following order under the regionalized scheme: returned discharge, supply to near grids, flow out of the basin, and retention storage. Under the generalized scheme, flow out of the basin exceeded supply to near grids, as described above. Retention storage was 3.2\% of total diverted canal flow (415 MCM) under the regionalized scheme and $649 \mathrm{MCM}$ under the generalized scheme (4.3\% of the total diverted canal flow), out of the total storage volumes of 615 MCM (regionalized scheme) and 935 MCM (generalized scheme; Table S3). Therefore, nearly $67 \%$ and $69 \%$ of the retention storage was utilized to store floodwater in the regionalized and generalized schemes, respectively.

In practice, water stored in low-lying retention areas of the CPRB (paddy fields) drains into canals and rivers after the flood, thereby creating space for water from upcoming floods in the same year. This process was not considered in the simulations, and the retention areas were assumed to accommodate floodwater only once per year until they became full. Because of this simplification, neither diversion canal scheme was able to reach the observed potential storage capacity (1701 MCM; Table S3). In addition, in the enhanced H08 model, retention areas are modeled such that the retention areas receive runoff in each grid cell; this runoff constitutes a portion of retention pond storage. Therefore, the maximum storage capacity of retention ponds (615 MCM and 935 MCM; Table S3) cannot be utilized for the storage of diverted floodwater. The storage capacity of the retention areas can be increased by changing the maximum water depth based on regional characteristics. 


\subsection{Impact of canal systems on flood control}

Initially, the impact of canal systems and retention areas on reducing the annual average discharge of the CPRB was analyzed. Fig. 7 shows discharge in the CPRB for various simulations averaged from 1980 to 2004; the regulated discharge simulation was excluded because of its negligible effect on annual average discharge. The maximum annual average discharge under the naturalized simulation was approximately $850 \mathrm{~m}^{3} / \mathrm{s}$ in the basin, which may lead to devastating impacts in the lower basin, including Bangkok City. A marked reduction in discharge, with values ranging between $500 \mathrm{~m}^{3} / \mathrm{s}$ and 583 $\mathrm{m}^{3} / \mathrm{s}$, occurred after enabling irrigation water abstraction (Fig. 7b). The impact of water diversion on annual average discharge shows that diversion has a great potential in the lower CPRB (Fig. 7c and d). In the regionalized simulation, the annual average discharge of the CPRB was approximately $523 \mathrm{~m}^{3} / \mathrm{s}$, a reduction of $10 \%$ from the irrigated simulation. In contrast, the generalized simulation portrayed a reduction of $28 \%$ in basin annual average discharge, compared with the irrigated simulation.

Although water diversion occurred from the Yom River to the Nan River, the impact of this diversion on annual average discharge was negligible. Moreover, the effect of this water diversion in the upper basin was nullified at C.2 station, where the Yom and Nan Rivers join. This finding elucidates the need for (i) water diversion systems to divert floodwater from the upper to lower basin, (ii) more retention areas to store floodwater, and (iii) other structural and non-structural measures. Jamrussri et al. (2018) also suggested that new retention areas adjacent to the Yom and the Nan Rivers are necessary to overcome severe flooding in the upper basin. The effect of water diversion on discharge is more pronounced in the lower CPRB.

Furthermore, the effect of canal operation on flood control was examined by calculating the number of flooding days (days during which daily discharge exceeded the channel carrying capacity) at various locations, as shown in Fig. 8. The number of flooding days are identical for naturalized and regulated simulations at Yom River stations because no dams are present in the Yom basin. The results from the Yom basin showed that the number of flooding days became zero at Y.4 and Y.17 stations in the regionalized simulation. Both schemes produced similar results for Y.16 station because of its small channel carrying capacity of $207 \mathrm{~m}^{3} / \mathrm{s}$. The reduction of flooding days was relatively small under the generalized scheme in the Yom basin. In the lower CPRB, the number of flooding days approached zero at C.2 station after the operation of upstream reservoirs; no water diversion system effects were found. Similarly, the effect of reservoirs was more pronounced at stations in the lower basin, compared with the effect of diversion canals. Both diversion schemes produced similar number of

475 flooding days, except at Ayutthaya (C.35 station). This difference at C.35 station can be explained by the low river channel carrying capacity and high canal carrying capacity at the origins of the Phong Pheng and Bang Ban canals in the regionalized simulation. Although the number of flooding days was significantly reduced in the regionalized simulation, the annual 
average discharge reduction was relatively small because most diverted water was returned to the river channel at some point downstream of the diversion.

Overall, both canal schemes reduced the flood risk, bringing the number of flooding days to nearly zero. Therefore, the incorporation of diversion canals in combination with reservoir operation could mitigate historic floods. However, climate change will aggravate the risk of flooding in the basin (Padiyedath Gopalan et al., 2021). In light of future climate change, new approaches combining structural and non-structural measures must be adopted in the CPRB.

\subsection{Applicability of the generalized canal scheme}

Although the generalized scheme showed some differences from the observations and regionalized scheme, it was able to identify the general pattern of flow diversion. The combined effect of canal systems in the generalized scheme was identical and comparable with the observations and regionalized scheme during the wet season, even though the effect of individual canals differs (Fig. 5; Table 4). However, it overestimated values during the dry season. Considerable overestimation of simulated canal flow was observed mainly for the Makham Thao-Uthong and Chainat-Ayutthaya canals (Fig. 5) during the wet season. This result was obtained because the main purpose of these canals is irrigation water supply, and they have low observed canal carrying capacities (Table S1). However, the generalized scheme considers the primary purpose of all canals to be flood control (because flood control is the primary objective of this study) and fixes the canal carrying capacity at the $\mathrm{Q}_{50}$ value, leading to the overestimation of canal flow. This generalized scheme can be improved by differentiating the purpose of each canal in the simulations, similar to the approach in the regionalized simulations.

The generalized canal scheme was able to produce an annual diversion pattern similar to the annual diversion pattern of the regionalized scheme (Fig. 6); diverted water comprised approximately $57 \%$ of the annual average river discharge in the CPRB. Although this result represents a slightly exaggerated discharge reduction scenario compared with the regionalized scheme (wherein $49 \%$ of annual average river discharge is diverted), it provides insight into the maximum level of discharge reduction that is achievable by maintaining environmental flow levels in the river channel. The generalized scheme showed a greater reduction of basin-wide annual average discharge, which can be attributed to the (i) increased carrying capacity of canals flowing out of the basin (Fig. S3), and (ii) greater retention area for storage of floodwater (Table S3). This finding reveals that the generalized scheme provides more control over the annual average discharge reduction, compared with the regionalized scheme (Fig. 7). Furthermore, the generalized scheme has a reasonable effect on the flood risk reduction, considerably reducing the number of flooding days (Fig. 8); thus, it can be regarded as the preliminary survey of future global applications using simple input data settings that can be derived from river discharge alone. 


\section{Discussion}

To our knowledge, this study is the first attempt to include flood diversion canals and retention areas into GHMs for controlling flood risk. The enhanced H08 model with the regionalized canal scheme successfully reproduced the observed flood diversion scenario in the study region. The generalized canal scheme exhibited performance comparable with the regionalized scheme for floodwater diversion. Using existing canal systems, both schemes could divert at least half of the annual average discharge in the CPRB, although some of the diverted discharge gradually returns to the river network. This return flow will increase the subsequent flood risk in downstream areas of the river, although the retention areas will reduce into nearby basins or the Gulf of Thailand, thereby reducing overall flood risk in the basin (JICA, 2018).

Impact assessment of both canal schemes in terms of river discharge revealed that the number of flooding days could be considerably reduced. Therefore, the enhanced H08 model provides a new tool for assessing future adaptation possibilities of the diversion canal systems. However, several uncertainties and limitations remain to be addressed in future studies. The limitations mainly arise from the assumptions made for river channel carrying capacity, canal carrying capacity, minimum flow of diversion, and the areal extent and depth of retention areas in generalized canal scheme simulations. Acquisition of observations and accurate representation of these variables in GHMs remain challenging tasks; this study represents a first step toward developing and incorporating a diversion scheme into the H08 GHM. The robustness of this scheme can be improved by adapting and applying it to different contexts and regions, accounting for the characteristics of each river network while maintaining the basic principles unaltered.

\section{Conclusions}

Assessing the impacts of flood diversion canals on flood risk reduction worldwide remains challenging. To overcome this issue, we developed a flood diversion canal operation scheme for the CPRB, a complex river network in Thailand with several natural and man-made diversion canals. The developed scheme was carefully designed and implemented into the H08 GHM for future floodwater management in complex river networks worldwide. A generalized canal scheme was also introduced with simple input data settings that can be derived from river discharge alone for application to data-scarce regions and periods. The major conclusions from this study can be summarized as follows:

1. A regionalized water diversion scheme was developed for the CPRB and incorporated into the H08 GHM to evaluate the effects of floodwater diversion on water-donating and its downstream areas, with the primary purpose of flood management. The validation results show that the diversion scheme can effectively simulate the observed flood diversion scenario in the CPRB. The generalized water diversion scheme with simple input data settings also exhibited comparable performance, especially during the wet season. 
2. The major share of the diverted water gradually returns to the destination points under both canal schemes. This indicates that although flood risk is reduced at the point of diversion, some risk remains in the destination area. If retention areas were able to hold more water, flood damage to residential and commercial areas of the lower CPRB could be reduced. This change can be achieved by (i) considering retention areas in irrigated and non-irrigated croplands simultaneously, (ii) assuming that the water from retention areas can be drained into canals and rivers after the floods using pumps; this makes the retention areas available for future floods in the same year, and (iii) increasing the depth of water stored in the retention areas (a depth of $1 \mathrm{~m}$ was assumed in this study).

3. Water diversion led to a marked reduction in the annual average discharge of the CPRB, which was much greater under the generalized canal scheme than the regionalized scheme. Furthermore, both canal schemes reduced the number of flooding days to nearly zero at most of the gauging stations considered. The overall simulation results indicate that currently implemented canal schemes have the potential to reduce flood risk in the upper and lower CPRB, where many industrial and residential areas are located. However, their abilities to overcome severe flooding should be further evaluated in the context of climate change.

Therefore, we emphasize that the regionalized canal scheme described herein was successfully applied to the CPRB, whereas the generalized scheme requires further validation to evaluate its applicability in other regions worldwide with slight modification. The water diversion rules implemented in the H08 model (during wet and dry seasons) can be easily adapted to different GHMs and should be examined for their applicability. In future research, we will expand upon these schemes for future applications by considering various adaptation scenarios.

\section{Code availability}

The source code and operation manual of $\mathrm{H} 08$ model is freely available from the following website: 560 https://h08.nies.go.jp/h08/index.html. The code for the diversion canal systems used in this study are available from the authors upon reasonable request.

\section{Data availability}

The meteorological data used in study is available from IMPAC-T project website (http://impact.eng.ku.ac.th/cc/). The remaining data that support the findings of this study are available from the authors upon reasonable request. 


\section{Author contribution}

SPG and NH conceived the idea. AC and TS acquired the data. SPG, NH, and SN analyzed and interpreted the data. SPG developed the model code and performed the simulations. SPG prepared the manuscript with contributions from all coauthors. NH, AC, TS, and SN reviewed and edited the manuscript.

\section{Competing interests}

570 The authors declare that they have no conflict of interest.

\section{Acknowledgements}

This study was carried out as a part of the research project entitled "Advancing Co-Design of Integrated Strategies with Adaptation to Climate Change in Thailand (ADAP-T)" supported by the Science and Technology Research Partnership for Sustainable Development (SATREPS) program of the Japan Science and Technology Agency (JST) and the Japan International Cooperation Agency (JICA).

\section{References}

Alfieri, L., Bisselink, B., Dottori, F., Naumann, G., de Roo, A., Salamon, P., Wyser, K. and Feyen, L.: Global projections of river flood risk in a warmer world, Earth's Futur., 5(2), 171-182, https://doi.org/10.1002/2016EF000485, 2017.

Bierkens, M. F. P.: Global hydrology 2015: State, trends, and directions, Water Resour. Res., 51(7), 4923-4947, https://doi.org/10.1002/2015WR017173, 2015.

Bond, H., Cross, K., Glotzbach, R., and Richaud, B.: Flood and drought management tools case study. Smart Water Management Project, Joint execution project by Danish Hydraulic Institute (DHI) and International Water Association (IWA), 229-232, 2018.

Boulange, J., Hanasaki, N., Yamazaki, D., Pokhrel, Y.: Role of dams in reducing global flood exposure under climate change, Nat. Commun., 12, 417, https://doi.org/10.1038/s41467-020-20704-0, 2021.

Burek, P., Satoh, Y., Kahil, T., Tang, T., Greve, P., Smilovic, M., Guillaumot, L., Zhao, F. and Wada, Y.: Development of the Community Water Model (CWatM v1.04) - A high-resolution hydrological model for global and regional assessment of integrated water resources management, Geosci. Model Dev., 13(7), 3267-3298, https://doi.org/10.5194/gmd-13-3267-2020, 2020.

590 Dankers, R., Arnell, N. W., Clark, D. B., Falloon, P. D., Fekete, B. M., Gosling, S. N., Heinke, J., Kim, H., Masaki, Y., Satoh, Y., Stacke, T., Wada, Y. and Wisser, D.: First look at changes in flood hazard in the Inter-Sectoral Impact Model 
https://doi.org/10.5194/hess-2021-532

Preprint. Discussion started: 2 December 2021

(c) Author(s) 2021. CC BY 4.0 License.
Hydrology and

Earth System

Sciences

Discussions

Intercomparison Project ensemble, Proc. Natl. Acad. Sci. U. S. A., 111(9), 3257-3261, https://doi.org/10.1073/pnas.1302078110, 2014.

Di Baldassarre, G., Viglione, A., Carr, G., Kuil, L., Salinas, J. L. and Blöschl, G.: Socio-hydrology: Conceptualising humanflood interactions, Hydrol. Earth Syst. Sci., 17(8), 3295-3303, https://doi.org/10.5194/hess-17-3295-2013, 2013.

Ehsani, N., Fekete, B. M., Vörösmarty, C. J., and Tessler, Z. D.: A neural network based general reservoir operation scheme, Stochastic Environ. Res. Risk Assess., 30, 1151-1166, http://dx.doi.org/10.1007/s00477-015-1147-9, 2016.

Ehsani, N., Vörösmarty, C. J., Fekete, B. M., and Stakhiv, E. Z.: Reservoirs operations under climate change: storage capacity options to mitigate risk, J. Hydrol., 555, 435-446, https://doi.org/10.1016/j.jhydrol.2017.09.008, 2017.

600 Hanasaki, N., Kanae, S., Oki, T., Masuda, K., Motoya, K., Shirakawa, N., Shen, Y., and Tanaka, K.: An integrated model for the assessment of global water resources-Part 1: Model description and input meteorological forcing, Hydrol. Earth Syst. Sci., 12, 1007-1025, https://doi.org/10.5194/hess-12-1007-2008, 2008a.

Hanasaki, N., Kanae, S., Oki, T., Masuda, K., Motoya, K., Shirakawa, N., Shen, Y. and Tanaka, K.: An integrated model for the assessment of global water resources - Part 2: Applications and assessments, Hydrol. Earth Syst. Sci., 12(4), 1027-1037, https://doi.org/10.5194/hess-12-1027-2008, 2008b.

Hanasaki, N., Yoshikawa, S., Pokhrel, Y. and Kanae, S.: A global hydrological simulation to specify the sources of water used by humans, Hydrol. Earth Syst. Sci., 22(1), 789-817, https://doi.org/10.5194/hess-22-789-2018, 2018.

Hirabayashi, Y., Mahendran, R., Koirala, S., Konoshima, L., Yamazaki, D., Watanabe, S., Kim, H. and Kanae, S.: Global flood risk under climate change, Nat. Clim. Chang., 3(9), 816-821, https://doi.org/10.1038/nclimate1911, 2013.

610 Hirabayashi, Y., Tanoue, M., Sasaki, O., Zhou, X. and Yamazaki, D.: Global exposure to flooding from the new CMIP6 climate model projections, Sci. Rep., 11(1), 3740, https://doi.org/10.1038/s41598-021-83279-w, 2021.

ICID (International Commission on Irrigation \& Drainage): Experiences in inter-basin water transfers for irrigation, drainage or flood management, Unpublished report, International Commission on Irrigation and Drainage ICID-CIID, New Delhi, 15 August 2005.

615 Indrawati, D., Hadihardaja, I. K., Adityawan, M. B., Pahrizal, S. F. and Taufik, F.: Diversion Canal to Decrease Flooding (Case Study: Kebon Jati-Kalibata Segment, Ciliwung River Basin), edited by D. Roosmini, K. Pribadi, B. Sugeng, and I. K. Hadihardaja, MATEC Web Conf., 147, 03006, https://doi.org/10.1051/matecconf/201814703006, 2018.

Jamrussri, S., Toda, Y. and Tsubaki, R.: Integrated flood countermeasures in the upper and middle Chao Phraya River Basin, J. Appl. Water Eng. Res., 7(2), 143-155, https://doi.org/10.1080/23249676.2018.1497559, 2018.

620 JICA (Japan International Cooperation Agency): Data Collection Survey on the Outer Ring Road Diversion Channel in the Comprehensive Flood Management Plan for the Chao Phraya River Basin in the Kingdom of Thailand, Final report (Summary), Pacific Consultants Co. Ltd., Oriental Consultants Co., Ltd., available at: https://openjicareport.jica.go.jp/pdf/12308631_01.pdf (last access: 20 April 2021), June 2018.

JICA (Japan International Cooperation Agency): Natural Disaster Risk Assessment and Area Business Continuity Plan 625 Formulation for Industrial Agglomerated Areas in the ASEAN Region, Country report, Thailand, OYO International 
Corporation, Mitsubishi Research Institute, Inc., CTI Engineering International Co., Ltd., available at: https://openjicareport.jica.go.jp/pdf/1000023397.pdf (last access: 20 April 2021), March 2015.

JICA (Japan International Cooperation Agency): Project for the comprehensive flood management plan for the Chao Phraya River basin, Final report, Volume 1: Summary Report, CTI Engineering International Co., Ltd., Oriental Consultants Co., Ltd., Nippon Koei Co., Ltd., CTI Engineering Co., Ltd., available at: https://openjicareport.jica.go.jp/pdf/12127205.pdf (last access: 20 April 2021), September 2013.

Jongman, B., Winsemius, H. C., Aerts, J. C. J. H., Coughlan De Perez, E., Van Aalst, M. K., Kron, W. and Ward, P. J.: Declining vulnerability to river floods and the global benefits of adaptation, Proc. Natl. Acad. Sci. U. S. A., 112(18), E2271E2280, https://doi.org/10.1073/pnas.1414439112, 2015.

635 Komori, D., Nakamura, S., Kiguchi, M., Nishijima, A., Yamazaki, D., Suzuki, S., Kawasaki, A., Oki, K. and Oki, T.: Characteristics of the 2011 Chao Phraya River flood in Central Thailand, Hydrol. Res. Lett., 6(0), 41-46, https://doi.org/10.3178/hrl.6.41, 2012.

Kotsuki, S., Tanaka, K. and Watanabe, S.: Projected hydrological changes and their consistency under future climate in the Chao Phraya River Basin using multi-model and multi-scenario of CMIP5 dataset, Hydrol. Res. Lett., 8(1), 27-32, https://doi.org/10.3178/hrl.8.27, 2014.

Kure, S. and Tebakari, T.: Hydrological impact of regional climate change in the Chao Phraya River Basin, Thailand, Hydrol. Res. Lett., 6(0), 53-58, https://doi.org/10.3178/hrl.6.53, 2012.

Lehner, B., Liermann, C. R., Revenga, C., Vörösmarty, C., Fekete, B., Crouzet, P., Döll, P., Endejan, M., Frenken, K., Magome, J., Nilsson, C., Robertson, J. C., Rödel, R., Sindorf, N. and Wisser, D.: High resolution mapping of global reservoirs and dams and their impact on downstream rivers, Front. Ecol. Environ., 9(9), 494-502, https://doi.org/10.1890/100125, 2011.

Manabe, S.: Climate and the ocean circulation 1. The atmospheric circulation and the hydrology of the earth's surface, Mon. Weather Rev., 97(11), 739-774, https://doi.org/10.1175/1520-0493(1969)097<0739:CATOC>2.3.CO;2, 1969.

Masaki, Y., Hanasaki, N., Biemans, H., Schmied, H. M., Tang, Q., Wada, Y., Gosling, S. N., Takahashi, K. and Hijioka, Y.: Intercomparison of global river discharge simulations focusing on dam operation - Multiple models analysis in two casestudy river basins, Missouri-Mississippi and Green-Colorado, Environ. Res. Lett., 12(5), 055002, https://doi.org/10.1088/1748-9326/aa57a8, 2017.

Masood, M., J.-F. Yeh, P., Hanasaki, N. and Takeuchi, K.: Model study of the impacts of future climate change on the hydrology of Ganges-Brahmaputra-Meghna basin, Hydrol. Earth Syst. Sci., 19(2), 747-770, https://doi.org/10.5194/hess-19$655747-2015,2015$.

Mateo, C. M., Hanasaki, N., Komori, D., Tanaka, K., Kiguchi, M., Champathong, A., Sukhapunnaphan, T., Yamazaki, D. and Oki, T.: Assessing the impacts of reservoir operation to floodplain inundation by combining hydrological, reservoir management, and hydrodynamic models, Water Resour. Res., 50(9), 7245-7266, https://doi.org/10.1002/2013WR014845, 2014. 

Balk, D., Boucher, T., Grill, G. and Montgomery, M.: Water on an urban planet: Urbanization and the reach of urban water infrastructure, Glob. Environ. Chang., 27(1), 96-105, https://doi.org/10.1016/j.gloenvcha.2014.04.022, 2014.

Mel, R. A., Viero, D. P., Carniello, L. and D’Alpaos, L.: Optimal floodgate operation for river flood management: The case study of Padova (Italy), J. Hydrol. Reg. Stud., 30, 100702, https://doi.org/10.1016/j.ejrh.2020.100702, 2020a.

Mel, R. A., Viero, D. Pietro, Carniello, L. and D’Alpaos, L.: Multipurpose Use of Artificial Channel Networks for Flood Risk Reduction: The Case of the Waterway Padova-Venice (Italy), Water, 12(6), 1609, https://doi.org/10.3390/w12061609, 2020b.

Müller Schmied, H., Caceres, D., Eisner, S., Flörke, M., Herbert, C., Niemann, C., Asali Peiris, T., Popat, E., Theodor Portmann, F., Reinecke, R., Schumacher, M., Shadkam, S., Telteu, C. E., Trautmann, T. and Döll, P.: The global water resources and use model WaterGAP v2.2d: Model description and evaluation, Geosci. Model Dev., 14(2), 1037-1079, https://doi.org/10.5194/gmd-14-1037-2021, 2021.

Nash, J. E. and Sutcliffe, J. V.: River flow forecasting through conceptual models. Part I - A discussion of principles, J. Hydrol., 10(3), 282-290, https://doi.org/10.1016/0022-1694(70)90255-6, 1970.

Nazemi, A. and Wheater, H. S.: On inclusion of water resource management in Earth system models -Part 1: Problem definition and representation of water demand, Hydrol. Earth Syst. Sci., 19(1), 33-61, https://doi.org/10.5194/hess-19-332015, 2015(a).

Nazemi, A. and Wheater, H. S.: On inclusion of water resource management in Earth system models Part 2: Representation of water supply and allocation and opportunities for improved modeling, Hydrol. Earth Syst. Sci., 19(1), 63-90, https://doi.org/10.5194/hess-19-63-2015, 2015(b).

680 Nugroho, J., Soekarno, I. and Harlan, D.: Model of Ciliwung River Flood Diversion Tunnel Using HEC-RAS Software, edited by D. Roosmini, K. Pribadi, B. Sugeng, and I. K. Hadihardaja, MATEC Web Conf., 147, 03001, https://doi.org/10.1051/matecconf/201814703001, 2018.

Padiyedath Gopalan, S., Hanasaki, N., Champathong, A. and Tebakari, T.: Impact assessment of reservoir operation in the context of climate change adaptation in the Chao Phraya River basin, Hydrol. Process., 35(1), e14005, 685 https://doi.org/10.1002/hyp.14005, 2021.

Padiyedath Gopalan, S., Kawamura, A., Amaguchi, H. and Azhikodan, G.: A Generalized Storage Function Model for the Water Level Estimation Using Rating Curve Relationship, Water Resour. Manag., 34(8), 2603-2619, https://doi.org/10.1007/s11269-020-02585-6, 2020.

Pokhrel, Y. N., Koirala, S., Yeh, P. J.-F., Hanasaki, N., Longuevergne, L., Kanae, S. and Oki, T.: Incorporation of 690 groundwater pumping in a global Land Surface Model with the representation of human impacts, Water Resour. Res., 51(1), 78-96, https://doi.org/10.1002/2014wr015602, 2015.

Prein, A. F., Rasmussen, R. M., Ikeda, K., Liu, C., Clark, M. P. and Holland, G. J.: The future intensification of hourly precipitation extremes, Nat. Clim. Chang., 7(1), 48-52, https://doi.org/10.1038/nclimate3168, 2017. 
Shumilova, O., Tockner, K., Thieme, M., Koska, A. and Zarfl, C.: Global Water Transfer Megaprojects: A Potential Solution

for the Water-Food-Energy Nexus?, Front. Environ. Sci., 6(DEC), 150, https://doi.org/10.3389/fenvs.2018.00150, 2018.

Siebert, S., Burke, J., Faures, J. M., Frenken, K., Hoogeveen, J., Döll, P. and Portmann, F. T.: Groundwater use for irrigation - A global inventory, Hydrol. Earth Syst. Sci., 14(10), 1863-1880, https://doi.org/10.5194/hess-14-1863-2010, 2010.

Sutanudjaja, E. H., Van Beek, R., Wanders, N., Wada, Y., Bosmans, J. H. C., Drost, N., Van Der Ent, R. J., De Graaf, I. E. M., Hoch, J. M., De Jong, K., Karssenberg, D., López López, P., Peßenteiner, S., Schmitz, O., Straatsma, M. W., Vannametee, E., Wisser, D. and Bierkens, M. F. P.: PCR-GLOBWB 2: A 5 arcmin global hydrological and water resources model, Geosci. Model Dev., 11(6), 2429-2453, https://doi.org/10.5194/gmd-11-2429-2018, 2018.

Takata, K. and Hanasaki, N.: The effects of afforestation as an adaptation option: A case study in the upper Chao Phraya River basin, Environ. Res. Lett., 15(4), 044020, https://doi.org/10.1088/1748-9326/ab7462, 2020.

Tamada, Y., Hoshikawa, K. and Funatsu, T. (Eds.): The 2011 Thailand Floods: Lessons and Records, Josei-Bunseki Report

No.22, Institute of Developing Economies, IDE-JETRO, Japan, 2013.

Tang, C., Yi, Y., Yang, Z. and Cheng, X.: Water pollution risk simulation and prediction in the main canal of the South-toNorth Water Transfer Project, J. Hydrol., 519(PB), 2111-2120, https://doi.org/10.1016/j.jhydrol.2014.10.010, 2014.

Tebakari, T., Yoshitani, J. and Suvanpimol, P.: Impact of large-scale reservoir operation on flow regime in the Chao Phraya River basin, Thailand, Hydrol. Process., 26(16), 2411-2420, https://doi.org/10.1002/hyp.9345, 2012.

710 Tourment, R., Beullac, B., Degoutte, G., Patouillard, S. and Maurin, J.: Levees, Diversion Canals or Flood Expansion Areas?, edited by M. Lang, F. Klijn, and P. Samuels, E3S Web Conf., 7, 12007, https://doi.org/10.1051/e3sconf/20160712007, 2016.

Wang, K., Wang, Z., Liu, K., Cheng, L., Wang, L. and Ye, A.: Impacts of the eastern route of the South-to-North Water Diversion Project emergency operation on flooding and drainage in water-receiving areas: An empirical case in China, Nat.

715 Hazards Earth Syst. Sci., 19(3), 555-570, https://doi.org/10.5194/nhess-19-555-2019, 2019.

Watanabe, S., Hirabayashi, Y., Kotsuki, S., Hanasaki, N., Tanaka, K., Mateo, C. M. R., Kiguchi, M., Ikoma, E., Kanae, S. and Oki, T.: Application of performance metrics to climate models for projecting future river discharge in the Chao Phraya River basin, Hydrol. Res. Lett., 8(1), 33-38, https://doi.org/10.3178/hrl.8.33, 2014.

Winsemius, H. C., Aerts, J. C. J. H., Van Beek, L. P. H., Bierkens, M. F. P., Bouwman, A., Jongman, B., Kwadijk, J. C. J.,

720 Ligtvoet, W., Lucas, P. L., Van Vuuren, D. P. and Ward, P. J.: Global drivers of future river flood risk, Nat. Clim. Chang., 6(4), 381-385, https://doi.org/10.1038/nclimate2893, 2016.

World Bank: Thai flood 2011, Rapid assessment for resilient recovery and reconstruction planning, Bangkok, Thailand, Joint Publication of World Bank and Global Facility for Disaster Reduction and Recovery. available at: https://www.gfdrr.org/sites/default/files/publication/Thai_Flood_2011_2.pdf(last access: 20 April 2021 ), 2012.

725 Ye, A., Duan, Q., Chu, W., Xu, J. and Mao, Y.: The impact of the South-North Water Transfer Project (CTP)'s central route on groundwater table in the Hai River basin, North China, Hydrol. Process., 28(23), 5755-5768, https://doi.org/10.1002/hyp.10081, 2014. 
https://doi.org/10.5194/hess-2021-532

Preprint. Discussion started: 2 December 2021

(c) Author(s) 2021. CC BY 4.0 License.

Yin, J., Gentine, P., Zhou, S., Sullivan, S. C., Wang, R., Zhang, Y. and Guo, S.: Large increase in global storm runoff extremes driven by climate and anthropogenic changes, Nat. Commun., 9(1), 1-10, https://doi.org/10.1038/s41467-018-
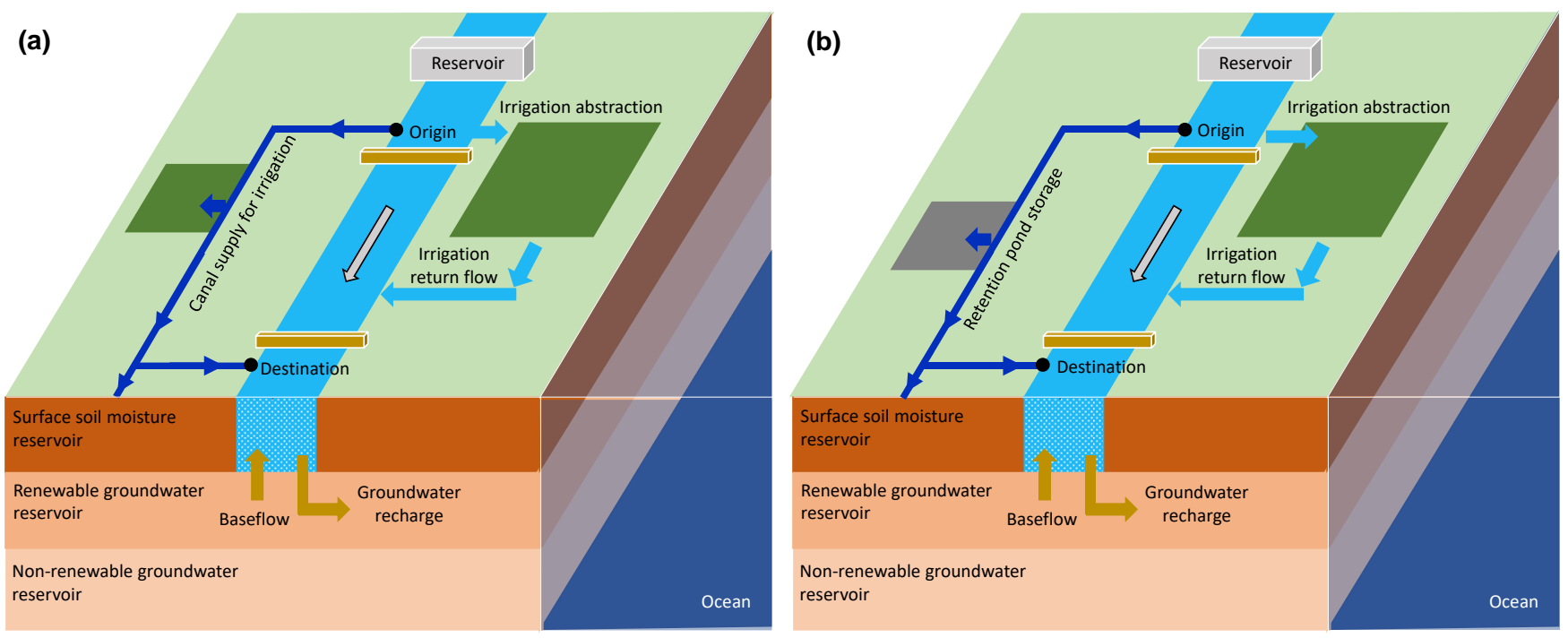

Figure 1: Schematic diagram of the canal diversion scheme of the enhanced H08 model during the (a) dry season and (b) wet season. Blue, green, orange, and grey symbols denote water, land, underground reservoirs, and retention areas, respectively. 


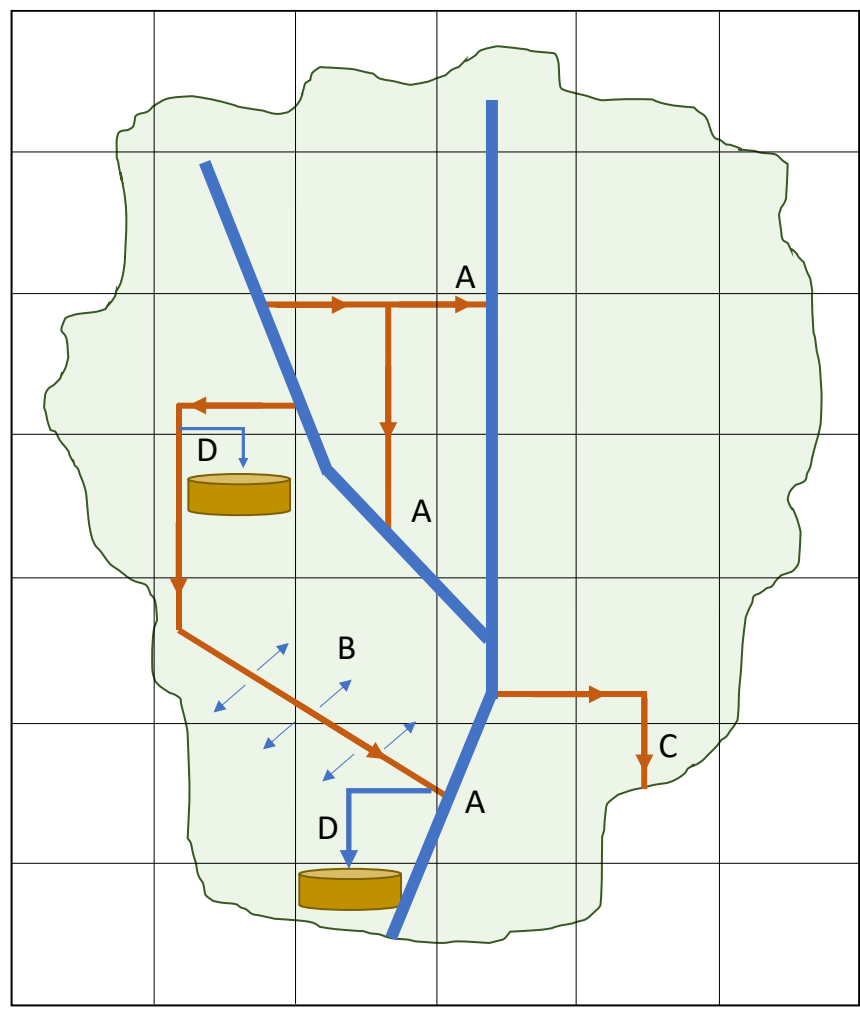

$$
\begin{array}{ll}
\text { A - Returned discharge } & \text { C- Flow out of the basin } \\
\text { B - Supply to near grids } & \text { D - Retention storage }
\end{array}
$$

Figure 2: Schematic diagram of the four major components of the diverted canal flow. The green coloured shape denotes the basin boundary. 
https://doi.org/10.5194/hess-2021-532

Preprint. Discussion started: 2 December 2021

(c) Author(s) 2021. CC BY 4.0 License.
Hydrology and

Earth System

Sciences

Discussions
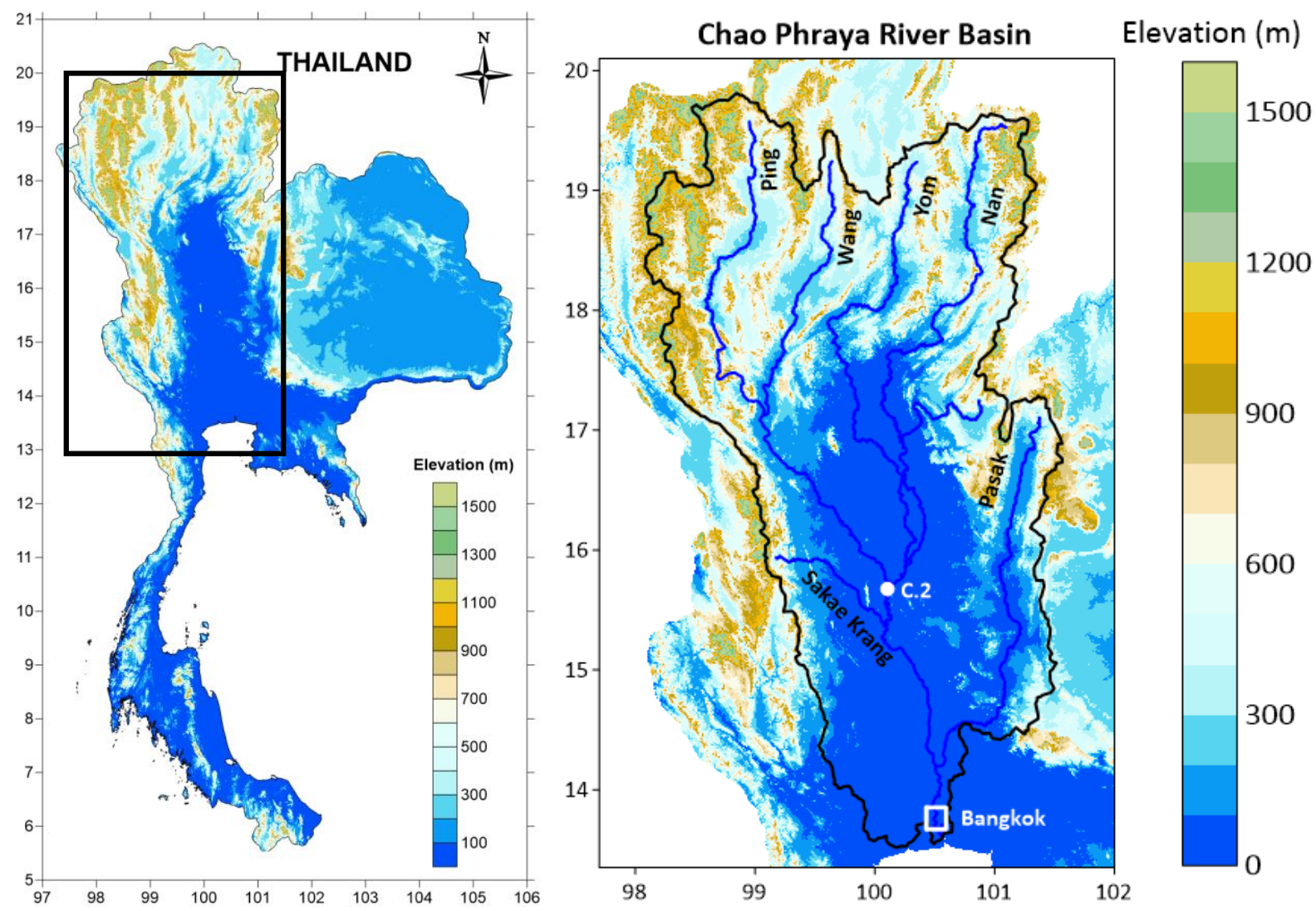

Figure 3: Left: Topographic map of Thailand in which the rectangle shows the location of the Chao Phraya River basin (CPRB).

Right: Topographic map of the CPRB with the major tributaries and the locations of the Nakhon Sawan (C.2 station) and Bangkok City. 
(a)

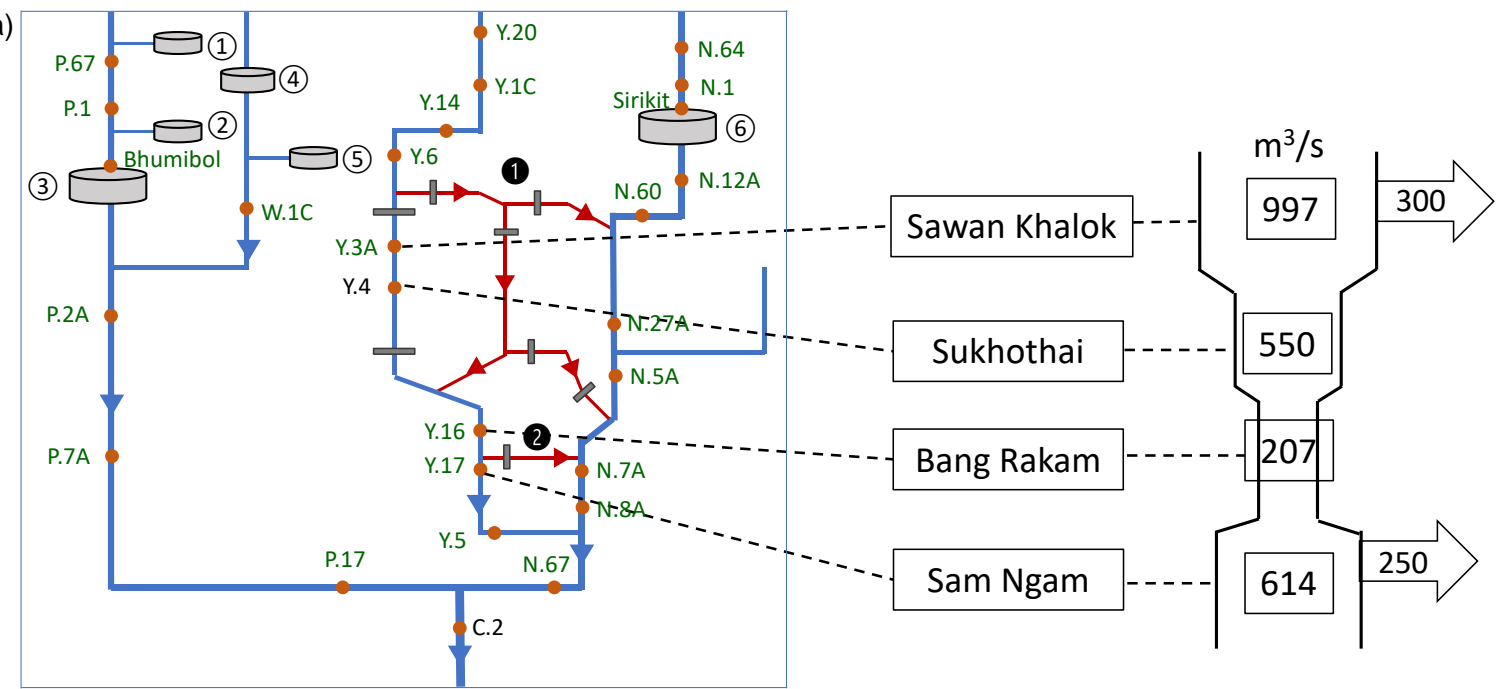

(b)

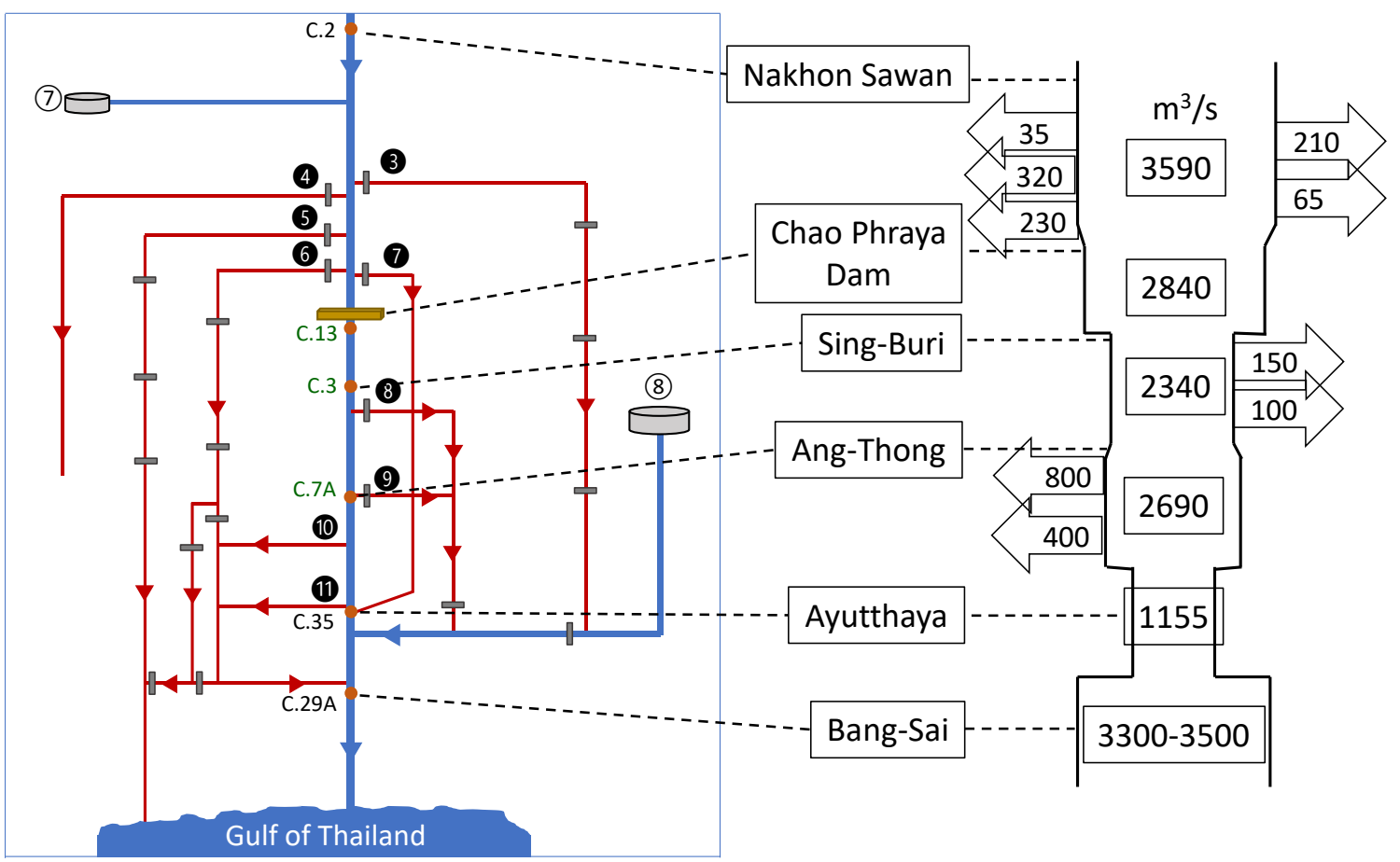

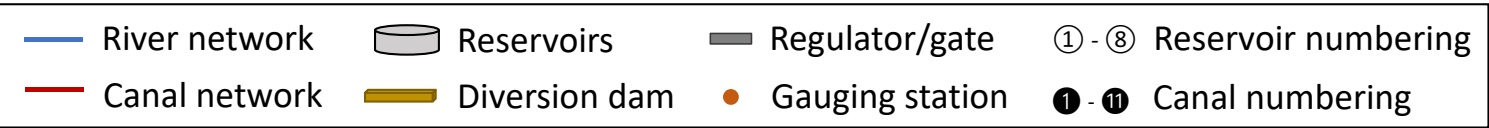

Figure 4: Left: Schematic diagram of different existing water infrastructures in the (a) upper CPRB and (b) lower CPRB. Right: River channel carrying capacity shown inside the river schematic and the canal carrying capacity shown in the left and right arrows for various locations within the CPRB. Please refer to Table 1 for the canal numbering and Table S2 for the reservoir numbering. The green colour gauging stations represent validation locations. 


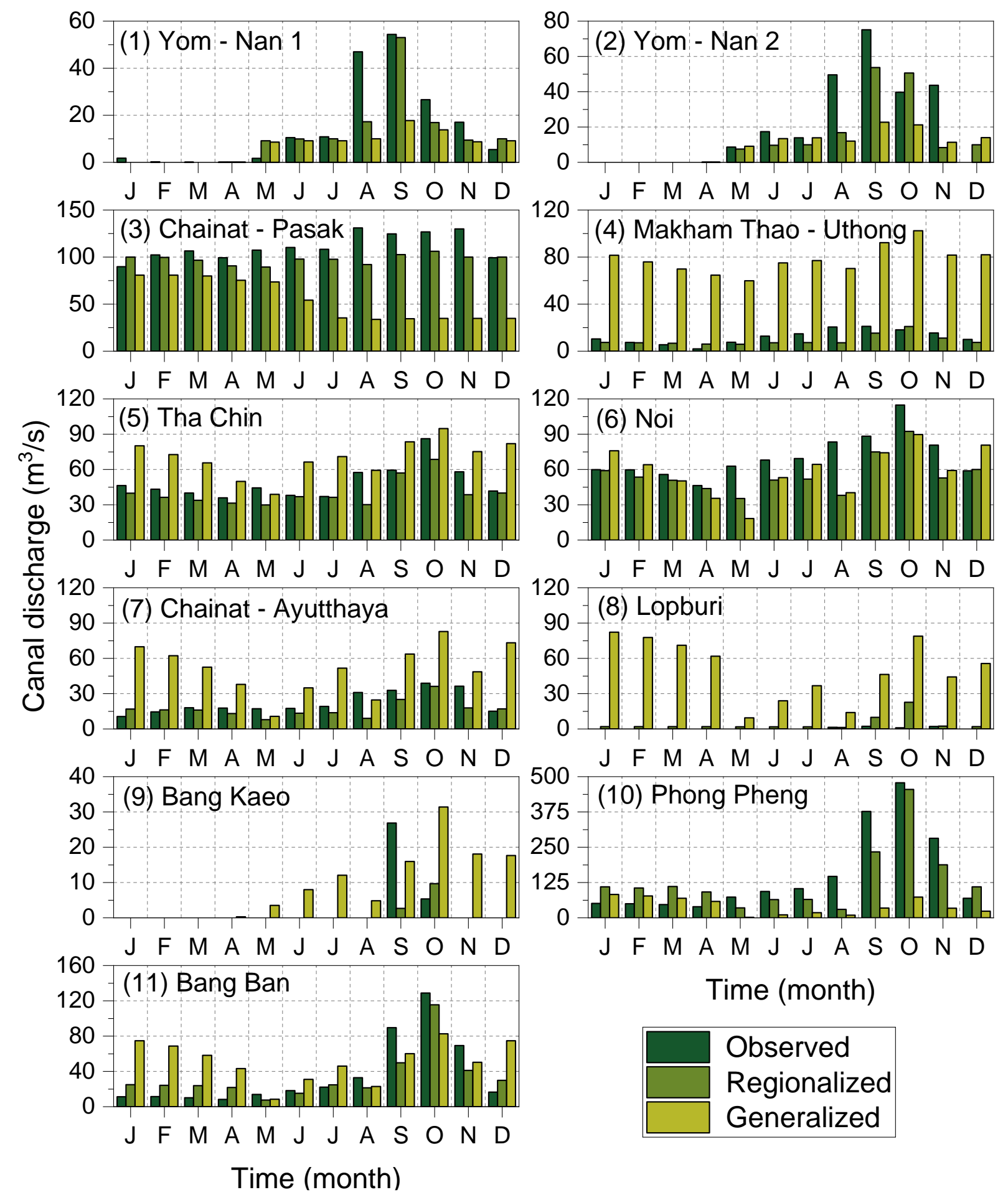

Figure 5: Simulated monthly mean canal discharge (regionalized and generalized) at 11 canal origins (in the order shown in Figure 4) compared with the observed flow. 


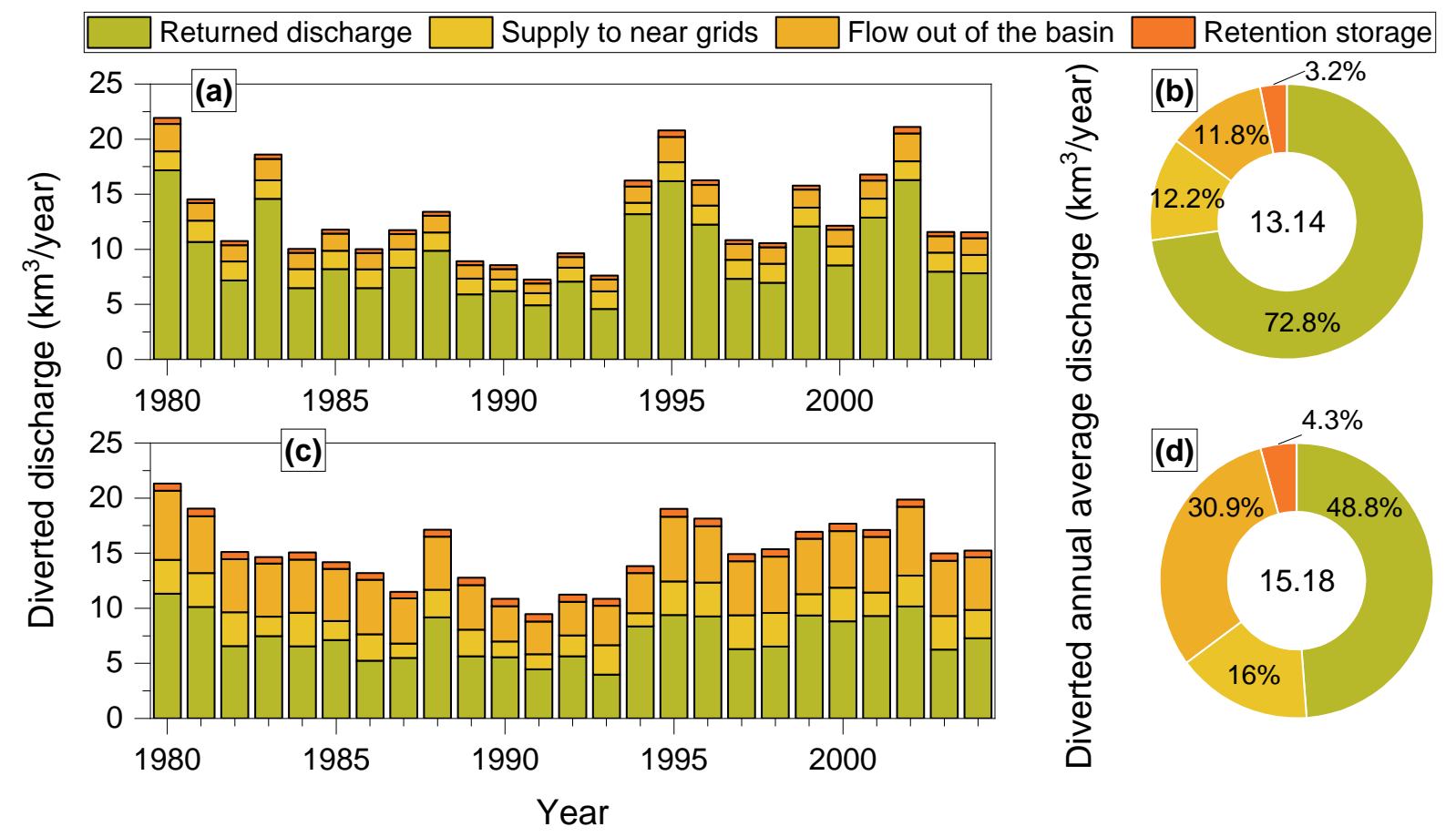

Figure 6: Amount of flow transferred from the canal systems to each of the components (from 1980-2004) and their percentage contribution to the annual canal flow averaged over 1980 to 2004 under the regionalized scheme (a and b) and generalized scheme (c and d).
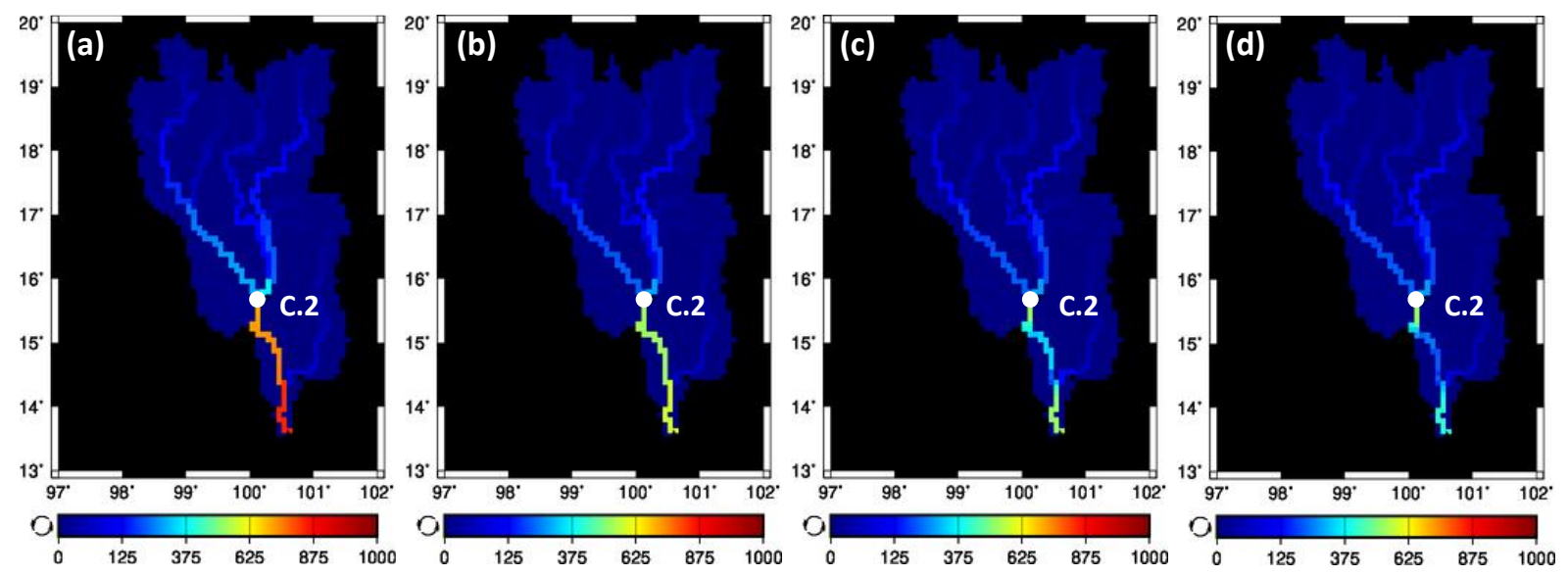

Figure 7: Annual average discharge in the CPRB for different simulations of (a) naturalized simulation, (b) irrigated simulation, (c) regionalized simulation, and (d) generalized simulation. 


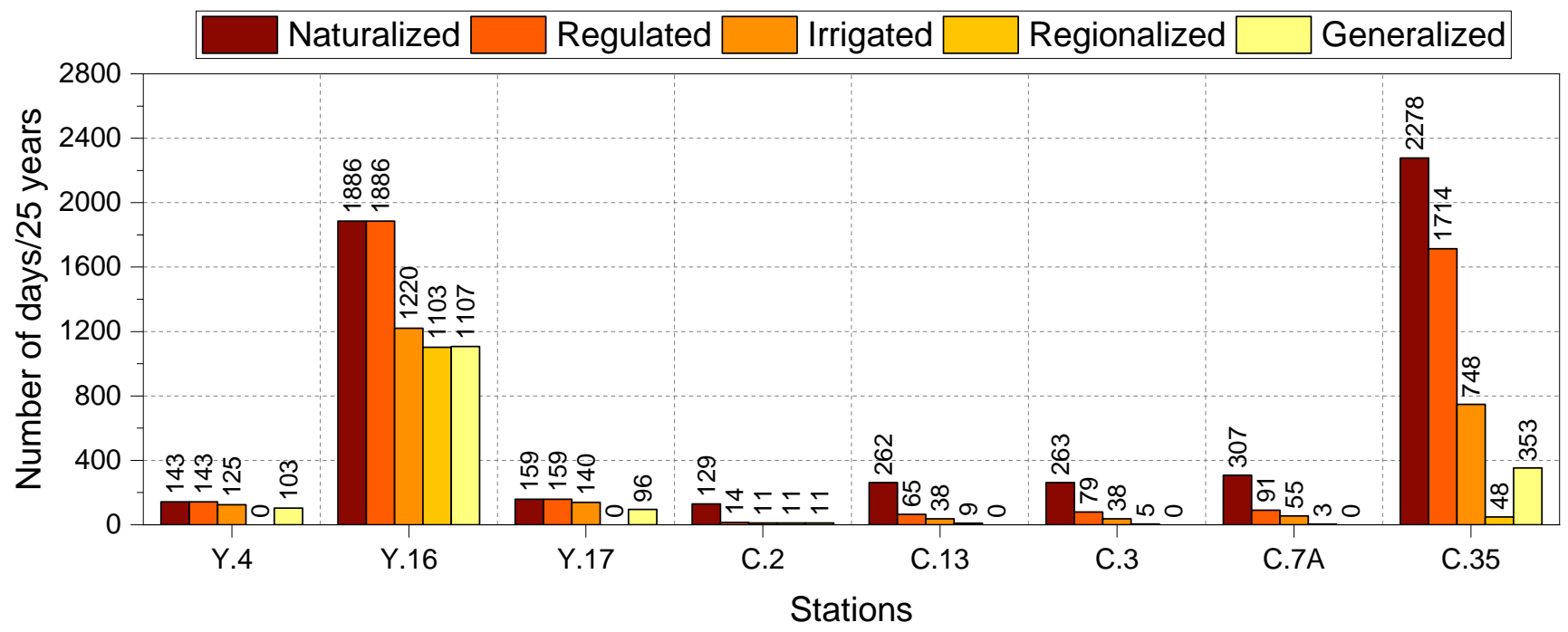

Figure 8: The number of days the daily discharge exceeded the channel carrying capacity at various locations from 1980-2004 (refer to Figure 4 for the channel carrying capacity of each station). 
Table 1. Origin and destination points of the canal systems in the CPRB with their regulating structures and purpose.

\begin{tabular}{|c|c|c|c|c|c|}
\hline No. & Canal system & Origin & Destination & Regulating structure & Purpose \\
\hline 1 & Yom - Nan 1 & Yom & $\begin{array}{l}\text { Nan, and } \\
\text { downstream of Yom }\end{array}$ & $\begin{array}{l}\text { Ban Hat Saphan Chan } \\
\text { barrage }\end{array}$ & Flood control \\
\hline 2 & Yom - Nan 2 & Yom & Nan & DR. 2.8 & Flood control \\
\hline 3 & Chainat - Pasak & $\begin{array}{l}\text { Chao } \\
\text { Phraya }\end{array}$ & Pasak & Manorom barrage & $\begin{array}{l}\text { Irrigation supply and } \\
\text { flood control }\end{array}$ \\
\hline 4 & $\begin{array}{l}\text { Makhamthao - } \\
\text { Uthong }\end{array}$ & $\begin{array}{l}\text { Chao } \\
\text { Phraya }\end{array}$ & Out of the basin & $\begin{array}{l}\text { Makamthao-Uthong } \\
\text { barrage }\end{array}$ & $\begin{array}{l}\text { Irrigation supply and } \\
\text { flood control }\end{array}$ \\
\hline 5 & Tha chin & $\begin{array}{l}\text { Chao } \\
\text { Phraya }\end{array}$ & Gulf of Thailand & Pholthep barrage & $\begin{array}{l}\text { Irrigation supply and } \\
\text { flood control }\end{array}$ \\
\hline 6 & Noi & $\begin{array}{l}\text { Chao } \\
\text { Phraya }\end{array}$ & Chao Phraya & Borommathat barrage & $\begin{array}{l}\text { Irrigation supply and } \\
\text { flood control }\end{array}$ \\
\hline 7 & Chainat - Ayutthaya & $\begin{array}{l}\text { Chao } \\
\text { Phraya }\end{array}$ & Chao Phraya & Maha Raj barrage & $\begin{array}{l}\text { Irrigation supply and } \\
\text { flood control }\end{array}$ \\
\hline 8 & Lopburi & $\begin{array}{l}\text { Chao } \\
\text { Phraya }\end{array}$ & Pasak & Lopburi barrage & Flood control \\
\hline 9 & Bang Kaeo & $\begin{array}{l}\text { Chao } \\
\text { Phraya }\end{array}$ & Lopburi & Bang Kaeo barrage & Flood control \\
\hline 10 & Phong Pheng & $\begin{array}{l}\text { Chao } \\
\text { Phraya }\end{array}$ & Noi & Gravity transfer & $\begin{array}{l}\text { Irrigation supply and } \\
\text { flood control }\end{array}$ \\
\hline 11 & Bang Ban & $\begin{array}{l}\text { Chao } \\
\text { Phraya }\end{array}$ & Noi & Gravity transfer & $\begin{array}{l}\text { Irrigation supply and } \\
\text { flood control }\end{array}$ \\
\hline
\end{tabular}


https://doi.org/10.5194/hess-2021-532

Hydrology and

Preprint. Discussion started: 2 December 2021

(c) Author(s) 2021. CC BY 4.0 License.

Table 2. The differentiation of regionalized and generalized canal schemes in terms of the input data (JICA, 2013; Tamada et al., 2013)

\begin{tabular}{lll} 
Input data & Regionalized canal scheme & Generalized canal scheme \\
\hline $\begin{array}{l}\text { Geographic location of canal origin and } \\
\text { destination }\end{array}$ & Observed & Observed \\
Location and areal fraction of retention areas & Areal extent of rainfed agriculture + Areal extent of rainfed \\
& Observed & agriculture \\
River channel carrying capacity $\left(Q_{\text {rivcap }}\right)$ & Adjusted & Q5 value \\
Canal carrying capacity $\left(Q_{\text {cancap }}\right)$ & Adjusted & Q50 value \\
Minimum flow diversion $\left(Q_{\text {min }}\right)$ & Adjusted & Q \\
Days of diversion in a year & Observed & Observed
\end{tabular}

Table 3. The different simulations carried out in this study.

\begin{tabular}{|c|c|c|c|c|}
\hline Simulations & $\begin{array}{l}\text { Reservoir } \\
\text { operation }\end{array}$ & $\begin{array}{c}\text { Irrigation water } \\
\text { abstraction }\end{array}$ & $\begin{array}{l}\text { Regionalized } \\
\text { canal scheme }\end{array}$ & $\begin{array}{l}\text { Generalized } \\
\text { canal scheme }\end{array}$ \\
\hline Naturalized & 凶 & 凶 & 冈 & 凶 \\
\hline Regulated & $\nabla$ & 凶 & 凶 & 凶 \\
\hline Irrigated & $\square$ & $\nabla$ & 冈 & 冈 \\
\hline Regionalized & $\square$ & $\nabla$ & $\nabla$ & 冈 \\
\hline Generalized & $\nabla$ & $\nabla$ & 冈 & $\nabla$ \\
\hline
\end{tabular}


Table 4. The observed and simulated fractions of diverted river flow to the canals under regionalized and generalized canal schemes during the wet and dry seasons.

\begin{tabular}{|c|c|c|c|c|c|c|c|}
\hline \multirow{2}{*}{$\begin{array}{c}\text { Canal } \\
\text { system }\end{array}$} & $\begin{array}{c}\text { Reference } \\
\text { gauging station } \\
\text { for canal water } \\
\text { diversion }\end{array}$ & \multicolumn{3}{|c|}{ Dry season (\%) } & \multicolumn{3}{c|}{ Wet season (\%) } \\
\cline { 3 - 8 } & Observed & Regionalized & Generalized & Observed & Regionalized & Generalized \\
\hline 1 & Y.14 & 0 & 0 & 0 & 19.91 & 20.75 & 13.22 \\
\hline 2 & Y.16 & 0 & 0 & 0 & 15.33 & 17.70 & 12.00 \\
\hline 3 & C.2 & 26.18 & 25.12 & 20.58 & 14.32 & 16.69 & 7.18 \\
\hline 4 & C.2 & 1.66 & 1.78 & 18.96 & 1.84 & 1.75 & 13.67 \\
\hline 5 & C.2 & 10.89 & 9.1 & 17.41 & 6.44 & 7.17 & 12.18 \\
\hline 6 & C.2 & 14.60 & 13.44 & 14.67 & 9.56 & 9.69 & 10.23 \\
\hline 7 & C. 2 & 4.00 & 4.04 & 14.45 & 3.17 & 2.98 & 8.33 \\
\hline 8 & C.3 & 0 & 0.71 & 81.70 & 0.13 & 1.52 & 15.42 \\
\hline 9 & C.7A & 0 & 0 & 0 & 0.83 & 0.43 & 5.89 \\
\hline 10 & C.7A & 36.45 & 34.60 & 43.36 & 41.97 & 41.48 & 10.86 \\
\hline 11 & C.7A & 8.02 & 7.84 & 36.93 & 10.12 & 10.73 & 19.88 \\
\hline & Average & 9.25 & 8.78 & 22.55 & 11.24 & 11.90 & 11.71 \\
\hline
\end{tabular}

